\title{
Identifying fiscal inflation in India: some recent evidence from an asymmetric approach
}

\author{
Javed Ahmad Bhat and Naresh Kumar Sharma \\ School of Economics, University of Hyderabad, Hyderabad, India
}

\begin{abstract}
Purpose - Among the many factors fueling the inflationary tendencies in an economy such as monetary shocks, structural shocks, demand shocks, external shocks and demographic changes, the issue of inflation (INF) has also been found to be related to fiscal policy decisions of the government. The purpose of this study is to investigate the inflationary tendencies in India particularly from the fiscal point of view. The study also examines the influence of other potential determinants such as output growth rate, interest rate, tradeopenness (TO) and oil price inflation (OPI).
\end{abstract}

Design/methodology/approach - To examine the dynamic nature of association between fiscal deficit and inflation, the study applies the Toda-Yamamoto (1995) test and Breitung and Candelon (2006) test to investigate the nature of causality in time and frequency domain frameworks. In addition, to scrutinize the possibility of a long-run association, that too from an asymmetric point of view, the study applies a Non-linear Autoregressive Distributed lag model (NARDL) given by Shin et al. (2014). Finally, non-linear cumulative dynamic multipliers are used to trace the traverse between disequilibrium position of short-run and subsequent long-run equilibrium of the system.

Findings - The authors found a unidirectional causality from fiscal deficit to inflation in case of time domain analysis and no feedback causality is reported. However, in case of frequency domain design, causality from fiscal deficit to inflation is found at low frequencies only, i.e. no short-run causality is established and hence dynamic nature of the relationship between the two variables is vindicated. Using NARDL model, the results document the existence of an asymmetric long-run direct association between fiscal deficit and inflation. However, an increase in deficit is found to be more inflationary and a decrease affects the inflation with a lower magnitude. The asymmetric impact of fiscal deficit on inflation can be explained through the existence of liquidity constraints, consumption-investment downward inflexibility and the downward price stickiness. Contractionary monetary policy action is found to be more effective than an expansionary one, signifying the asymmetric influence of monetary policy actions on the inflation of India.

(C) Javed Ahmad Bhat and Naresh Kumar Sharma. Published in Journal of Economics, Finance and Administrative Science. Published by Emerald Publishing Limited. This article is published under the Creative Commons Attribution (CC BY 4.0) license. Anyone may reproduce, distribute, translate and create derivative works of this article (for both commercial and non-commercial purposes), subject to full attribution to the original publication and authors. The full terms of this license may be seen at http://creativecommons.org/licences/by/4.0/legalcode

We thank Greenwood Nimmo for providing estimation code for NARDL model and the editorial staff of this journal. We also thank one anonymous referee for his useful inputs and meticulous evaluation of our work journal. Usual disclaimer applies.

Disclosure statement: No potential conflict of interest was reported by the authors. Please note, this paper is also available at SSRN: https://papers.ssrn.com/sol3/papers.cfm?abstract_id=3139459.

Author contributions: The authors contributed in the following ways to the paper: Bhat, Javed Ahmad, Corresponding Author, Conceptualization (Equal), Data curation (Equal), Formal analysis (Equal), Investigation (Equal), Methodology (Equal), Writing-original draft (Lead), Writing-review and editing (Equal), Sharma, Naresh Kumar, Conceptualization (Equal), Data curation (Equal), Formal analysis (Equal), Investigation (Equal), Methodology (Equal), Supervision (Lead), Validation (Equal), Writing-review and editing (Equal).

Identifying fiscal inflation in India

Received 8 March 2019 Revised 14 May 2019 Accepted 14 May 2019 
JEFAS 25,50

Similarly, in a supply-constrained economy with downward price rigidity, the authors found an asymmetric impact of output growth and output decline on inflation. As regard to the trade-openness, although an asymmetry is reported, the signs refute the validation of Romer (1993) hypothesis. Finally, the impact of oil price inflation on the inflationary pressures is according to theory but the coefficients are devoid of statistical significance.

Practical implications - These results indicate some important policy recommendations. Fiscal consolidation strategy should be executed in an appreciable manner to achieve the sound fiscal health and lower INF. The disciplined fiscal strategy would also be imperative for an effective monetary policy. Monetary authorities should possess noticeable credibility to manage the macroeconomic system and policy stances should be implemented according to requirements of the economy. Growth in output should be encouraged to have twofold benefits to the economy - reducing INF on the one hand and fiscal deficits on the other.

Originality/value - The study contributes to the existing literature in the following ways. First, taking note of dynamic nature of the relationship between these two variables, the study examined the deficit INF nexus in a dynamic and asymmetric framework. The novelty of the study is ensured by the very nature of it is the first study in case of India to identify the fiscal INF in an asymmetric configuration. The authors applied a NARDL model, given by Shin et al. (2014) to examine the existence of any cointegrating relationship in an asymmetric paradigm. Second, the nature of causality between fiscal deficit and INF has been examined in a time domain and FD framework to portray precisely the casual interactions between these two variables in the short-run and long run. The study will, therefore, enrich the existing literature along the asymmetric lines.

Keywords India, Inflation, Asymmetry, Casuality, Fiscal deficit, Output growth

Paper type Research paper

\section{Introduction}

Higher inflation (INF) has been considered a growth retarding factor and a means of reducing the welfare standard of common masses. Therefore, maintaining a stable price level featured by low INF rate has remained a priority objective of macroeconomic management of various economies including India. Among the many factors fueling the inflationary tendencies in an economy such as monetary shocks, structural shocks, demand shocks, external shocks and demographic changes, the issue of INF has also been found related to fiscal policy decisions of the government. The fiscal theory of price level (FTPL) (Leeper, 1991; Sims, 1994 and Woodford, 2001) and the seminal work of Sargent and Wallace (1981) developed the theoretical contours for the establishment of an interaction between inflationary pressures in an economy and the government budgetary imbalances. The former talks about the complementarity between monetary and fiscal policies for the price level determination; and on policy plane, the theory suggests the sustainability of government finances to ensure the stable price level. The latter highlights the role of relative dominance of monetary/fiscal authorities in the determination of the price level. In a monetary dominance regime, fiscal authorities abide with the decisions of independently determined monetary policy and are constrained to follow a fiscal discipline strategy to avoid the inflationary pressures in the economy. On the contrary, in a fiscal dominance regime, the fiscal authorities determine the level of current and future fiscal imbalances and thereby constrain the monetary authority for the demand of government bonds. This leads to excess money creation through debt monetization, and hence, inflationary tendencies emerge [1]. The deficit could be financed either through the imposition of higher taxes or domestic or external borrowings. However, developing countries quite often finance their deficit through debt monetization because of the high costs associated with higher tax rates, political instability and market borrowings. As a result, fiscal view of INF is more often reported in the developing countries than in the developed countries, which are seen to have efficient tax collection system and considerable access to external borrowings (Catao and Terrones, 2005).

The present paper aims at examining the impact of fiscal deficit on the inflation in case of Indian economy. Though several studies have been conducted in the Indian context, the 
deficit-INF nexus has not been evaluated exhaustively and the evidence reported by earlier studies remained inconclusive. India is chosen as a candidate for analysis because of its vibrant INF dynamics and its observed downward inflexibility of deficit financing (Figures 1 and 2). The deficit financing has always been considered a viable instrument to avoid any recessionary tendencies in the economy. Recognizing the adverse impacts of excess deficit, the government followed the fiscal consolidation program through the FRBM Act[2] (2003-04) and finalized the pro-growth targets for fiscal imbalances. However, the recent fiscal response to the 2008 global crisis, following the suspension of fiscal targets, not only enabled India to avoid the crisis at home but also to continue along its growth trajectory as well. The move, however, represented a deviation from the fiscal discipline path. Even though the efforts have been made to curtail the deficit figures appreciably, the economy is still plagued with persistent deficit of

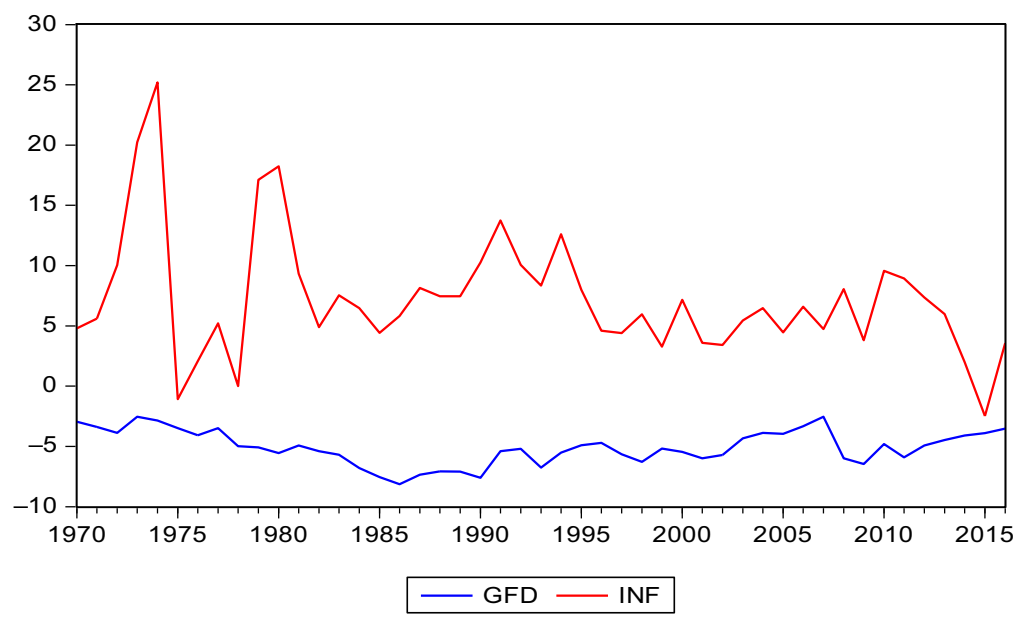

Source: Own elaboration

Figure 1. INF rate and fiscal deficit as a percentage of GDP

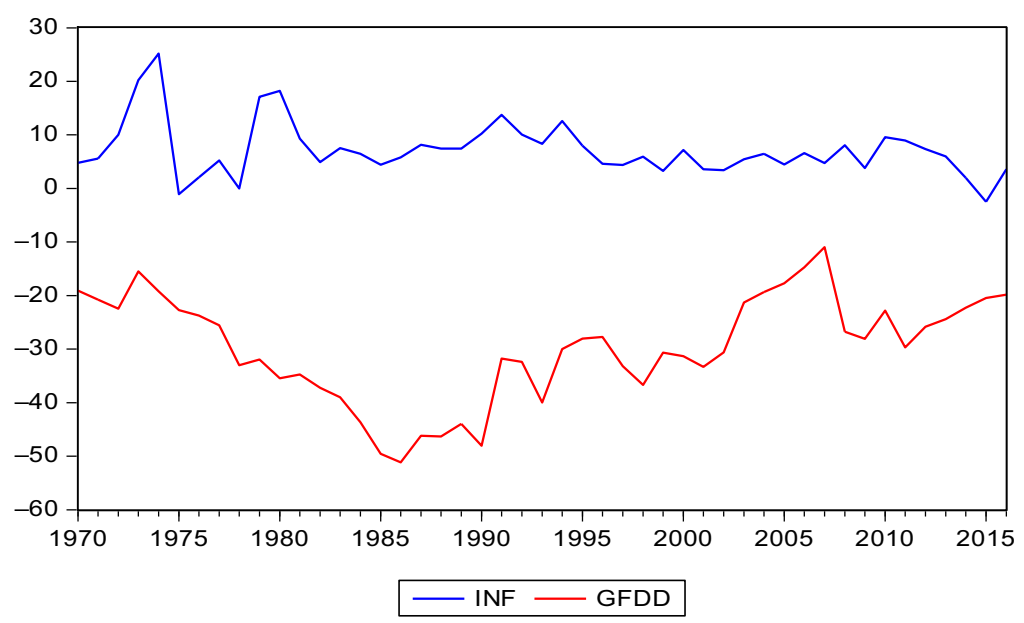

Figure 2. INF rate and fiscal deficit as a percentage of narrow money

Source: Own elaboration 
JEFAS

25,50

366

$3.52 \%$ of gross domestic product (GDP) in 2016-17[3]. In light of swelling deficit figures and vibrant inflationary phenomenon, as observed from the Figures 1 and 2 in the economy, it would, therefore, be important to examine the possible interaction between these two variables.

Though the inflationary pressures in India have been theoretically ascribed to both domestic and foreign factors and to both supply and demand shocks, however, the empirical evidence reported remains inadequate (Mohanty and John, 2015). The possible reason for such an inadequacy could be the changes in determinants of INF over the period of time (Mohanty and John, 2015). Given the backdrop, we attempted to analyze the inflationary phenomenon from the viewpoint of fiscal deficit to sort out the likely role of the latter in explaining the overall INF. Work reported is motivated by lack of adequate literature so far as India is concerned and mixed evidence reported in the general literature on the deficit-INF nexus. The study adopts a broader analytical framework to include all the potential determinants of INF in addition to fiscal deficit. Data for the period 1970-2016 has been examined to provide an evaluation of Indian inflationary problem with some recent evidence. The paper hopes to contribute to the existing literature in the following ways. First, taking note of dynamic nature of the relationship between these two variables, we examined the deficit INF nexus in a dynamic and asymmetric framework. The novelty of the study is ensured by the very nature of it is the first study in case of India to identify the fiscal INF in an asymmetric configuration. We applied a non-linear autoregressive distributed lag model (NARDL), given by Shin et al. (2014) to examine the existence, if any, of cointegrating relationship in an asymmetric paradigm. This method has been applied because of its potential merits over the other conventional linear approaches. Second, the nature of causality between fiscal deficit and INF is examined in time domain and FD frameworks to portray precisely the casual interactions between these two variables in both the short-run and long run.

The studies so far conducted, have primarily based their analysis within a linear or symmetrical framework and have ignored the possibility of any asymmetric nature of the association between the two variables. The severe repercussions of this practice of assuming a symmetric association may lead to incorrect policy actions as may be needed for overall macroeconomic stability. The choice of an emerging economy, India, for the asymmetric investigation of deficit-INF nexus is motivated by the prevalence of a large section of liquidity constrained population together with persistent inequalities (Mazumdar et al., 2017; Bhat and Sharma, 2018). The lack of purchasing power, liquidity tightening and a distorted credit allocation system as prevalent in India together with the operation of consumption/investment downward inflexibility makes it likely that the response of INF to fiscal deficit may not be symmetric.

The remaining part of the paper is arranged as follows. Section 2 specifies the theoretical debate. A cursory summary of the relevant literature is reported in Section 3. Section 4 narrates the nature of variables and exposition of the econometric method to be used, followed by result discussion in Section 5. Finally, the paper conclusion and associated policy recommendations are highlighted in Section 6.

\section{Theoretical debate}

Theoretically, various views have been advocated about the impact of fiscal deficit on INF. Neoclassical theory asserted a positive relationship between the two through higher money demand. When the income of the economic agents rise, more money is needed to facilitate the transactions due to increased incomes. Demand for real balances increase because of the rise in level of real income and hence leads to hike in the price level (Ball, 2017). The Keynesians also provide another channel for a direct association between fiscal deficit and INF like those of Elmendorf and Mankiw (1999)[4] through aggregate demand augmentation. The collapse of Bretton woods system in 1971, which resulted in the era of 
flexible exchange rate (EXR) regime and the oil price shock of 1970s led to the breakdown of celebrated Philips curve hypothesis. This lead to the development of Monetarist school and the pioneer of which, Milton Friedman, maintained that INF is always and everywhere a monetary phenomenon and that money supply growth that may result because of deficit financing causes INF.

The impact of fiscal deficits on INF has also been discussed in the celebrated work of Sargent and Wallace (1981) in a framework of "monetary dominance" and "fiscal dominance" regimes. The deficit is financed either through bond sales to the public or through the seigniorage created by monetary authority or by a combination of both. In the case of an independent monetary authority framework, fiscal authority is constrained in the formulation of its policy. In this regime of monetary dominance, money supply is regulated and fiscal deficits would tend to be non-inflationary. On the contrary in a fiscal dominance regime, the regulation of money supply by the monetary authorities becomes less effective and fiscal authorities satisfy the inter-temporal budget constraints through the excess money creation, in the process leading to INF. While the monetarists ascribe the tag of the monetary phenomenon to INF, Fischer and Easterly (1990) regarded the inflationary tendencies as being a fiscal phenomenon. In reality, fiscal authorities have often preferred seigniorage to finance the fiscal imbalances, thereby triggering the inflationary pressures.

There is yet another recent theoretical premise arguing for the nature of the relationship between fiscal deficit and INF, namely, the FTPL, given by Woodford (1994, 1995, 2001), McCallum (2001), Cochrane (2001, 2005) and Leeper and Yun (2006). According to FTPL, the price level in an economy is not determined individually by monetary authorities alone, but complementarity of both monetary and fiscal policies is operative. When the fiscal authorities make an adjustment to the present value of its future surpluses, the price level will rise to lower the real value of debt[5]. In FTPL, fiscal authorities are permitted to choose the surplus or deficit figures, not necessarily conducive for fiscal solvency. Thus because of the exogenous character of fiscal actions, endogenous movement of the price level is required to achieve fiscal solvency. The fiscal policy, thus, becomes a leader and monetary policy a follower, controls only the timing of INF and with the result, fiscal deficit tend to be inflationary. Minford and Peel (2002), therefore, asserted that price level and fiscal policy are linked through the present value of the corresponding budget constraint [6]. INF may not be a result of money creation only, but in a dominant fiscal policy regime, where the fiscal policy is not sustainable and government bonds are considered net wealth, the wealth effects could compromise the objective of price stability irrespective of central bank's commitment to control INF (Ramu and Gayithri, 2017).

It is important to note that the association between deficits and INF is a dynamic one Sargent and Wallace (1981), Catao and Terrones (2005) and Lin and Chu (2013). In a fiscal dominance regime, fiscal deficit provide an estimate of future and not the current money creation (seigniorage) required for their financing, and hence, do not lead to current INF. This is because of the fact that borrowing enables fiscal authorities to allocate the seigniorage inter-temporally, and thus, refute the existence of any contemporaneous association. In addition, the short-run association between the two variables can be multiplex (Dornbusch et al., 1990), can involve a possible feedback of INF on fiscal deficits (Catao and Terrones, 2005) and hence its direction and strength may not be accommodative to theoretical analogies. Therefore, the empirical examination between these two variables would be analyzed from a long-term perspective.

\section{Empirical review}

\subsection{General literature}

The issue of INF has always been at the core of theoretical and empirical debates. Scholars have analyzed the inflationary tendencies in various countries with different data sets, 
JEFAS

25,50

different determinants and different econometric methodologies. So far, as the impact of fiscal deficit on the INF is concerned, Hamburger and Zwick (1981) found the inflationary nature of budget deficit while analyzing the USA data for a period 1954-1976. The authors also found budget deficit more inflationary in the Keynesian regime (1961-1974). However, Dwyer (1982) failed to document any evidence in favor of influence of debt on the money supply and overall price level in the economy. On the contrary, Ahking and Miller (1985) reported the evidence of deficit-INF relationship only in some specific periods. Similarly, Darrat (1985) found money growth and fiscal deficit as the significant determinants of increased price levels. Applying a neo-classical framework, King and Plosser (1985) reported the existence of weak deficit-INF relationship. Moreover, King and Plosser (1985) failed to uncover any such relationship while examining a mix of 12 developed and developing countries.

Examining the data from 10 developed countries, Giannaros and Kolluri (1985) found the absence of any kind of relationship between INF, money supply and fiscal deficit. Similarly, using the data over the period 1952-1987, Protopapadakis and Siegel (1987) also reported the existence of a feeble association between these two variables in another set of 10 developed economies. In addition, INF is not found to respond debt growth strongly. In another study on seven industrial economies, Barnhart and Darrat (1988) found the absence of any unidirectional or feedback Granger causality between these INF and fiscal deficit.

In case of 17 developing countries and for a time period from 1961 to 1985, De Haan and Zelhorst (1990) found the absence of any evidence in favor of "fiscal dominance hypothesis" and reported that INF reacts to deficit only during high INF episodes. Metin (1998) documented the inflationary impact of fiscal deficit in case of Turkey. However, analyzing the data on three transition economies, Komulainen and Pirttilä (2002) reported the neutrality of fiscal deficit in explaining the inflationary tendencies in these economies. Similarly, Loungani and Swagel (2001) found puny association between fiscal balance and INF in case of 53 developing countries. However, the relationship becomes stronger in case of economies with higher average INF. The authors further reported the non-linear influence of fiscal imbalances on INF and found that the former affects the latter significantly only when the magnitude of former is above $5 \%$. Domaç and Yücel (2005) while applying pooled probit estimation in case of 15 emerging economies documented the inflationary role of fiscal deficit. Recently, Nguyen (2015) also reported the evidence of fiscal INF in case of eight selected economies of Asia.

Some scholars were interested to examine the deficit-INF nexus in case of a mix of developed and developing countries together in a panel setting and reported diversity of results. For instance, Karras (1994) found absence of any impact of deficit on INF in case of a panel of 32 developed and developing countries. Similarly, examining a panel of 90 countries, Click (1998) reported the absence of any impact of domestic debt on INF over the period 1971-1990. However, Cottarelli et al. (1998) found the inflationary nature of deficit along with INF persistence in case of a mixed panel of 47 countries. Similarly, Laasch et al. (2002) found the evidence in favor of fiscal INF by examining a mixed panel of 94 economies. The study further reported the significant role of fiscal deficit in determining the seigniorage and INF in case of high INF periods and in case of countries with high average INF. Catao and Terrones (2005) examined a data set comprising of 109 countries over a period of 19602001 to investigate the dynamic nature of interactions between these two variables. The study documented the evidence of inflationary nature of deficit figures in case of transition economies and in the economies featured with high episodes of INF but not in case of advanced economies and those experiencing lower INF levels. Similarly, examining the larger data set over the period 1962-2004 for a mixed panel of 71 countries, Kwon et al. (2009) found the positive and appreciable impact of debt growth on the INF in case of countries plagued with massive debts but, however, the impact is low in remaining cross-sections of 
panel. Likewise, Lin and Chu (2013) while analyzing the data on 91 countries for a period 1960-2006, found the results more or less similar to that of Catao and Terrones (2005). More recently, Tran (2018) investigated the asymmetric impact of fiscal balance on the key monetary variables such as interest rate, INF and EXR in case of four emerging economies such as BRIC for the period 1999-2000. The study found the long-run association between fiscal balance and monetary variables in case of countries such as Brazil and India, whereas no such association is found for China and Russia. In addition, the deterioration of fiscal balance is found to have a more powerful and significant impact on the monetary variables than when it improves.

\subsection{Studies specific to India}

The deficit INF interaction has also been examined in the case of Indian economy. Sarma (1982) and Rangarajan and Mohanty (1998) have found the existence of a perennial interaction between fiscal deficit and INF in both forward and feedback directions. In addition, these studies have reported the fiscal deficit among the important determinants of INF in India. The outcome of these studies is relevant to the prevailing conditions of that time. With the permanent blockade of ad hoc treasury bills in 1996-1997, market borrowings used to finance deficit ceased as an option and mode of monetization was resorted. However, even after accounting for monetization period of deficit financing in an extended data set analysis, Ashra et al. (2004) reported the absence of long-run association between Reserve Bank credit and fiscal deficit and between money and Reserve Bank credit to the government. The study, therefore, recommended the scrapping of fiscal deficit as a stabilization tool. Using a more recent data set and an updated methodology, Khundrakpam and Goyal (2009) reported the significant contribution of fiscal deficit in the incremental reserve money creation and overall money expansion, which finally leads to INF in the economy. Similarly, Khundrakpam and Pattanaik (2010) found the inflationary role of fiscal imbalances. RBI (2012), also reported evidence in favor of the fiscal INF in India. Mohanty and John (2015) applied the time-varying structural VAR procedure to analyze the timevarying impact of various determinants of INF in India. This study reported the inflationary impact of fiscal deficit. More recently, Ramu and Gayithri (2017) found the inflationary impact of fiscal deficit in India. Through a SVAR approach the authors have documented the evidence of three transmission channels such as consumption expenditure channel, money supply channel and import channel to portray the traverse of the impact of fiscal deficit on INF. However, no evidence in favor of interest rate channel is observed.

The above literature survey highlighted certain important points. On average deficits are reported to be less inflationary in advanced and low INF countries characterized by sound and credible monetary authorities and less fiscal dominance. However, in developing countries with higher INF rates and high INF episodes, the deficits are found to be inflationary. There is an inconclusiveness documented about the impact of the deficit on INF in general and India in particular A limitation of the existing literature is that the analytical framework adopted for the empirical exercise is largely symmetric/linear and the possibility of any asymmetric nature of the relationship is omitted[7]. To fill this void, the present study, therefore, is an attempt to analyze the inflationary impact of fiscal deficit in a dynamic and asymmetric framework. Our study will, therefore, enrich the existing literature along the asymmetric lines.

\section{Data description and empirical methodology}

\subsection{Data description}

The selection of the variables for the empirical analysis is guided by the prevalent theoretical propositions and the existing empirical evidence. The data set is of annual 
JEFAS 25,50

frequency covering the period 1970 to 2016. The variables include INF, gross fiscal deficit (GFD), narrow money (NM), GDP, real GDP growth rate (GDPFC), interest rate (CMR), Trade-openness (TO), EXR and OPI.

The data on all the variables (except OPI) has been taken from Database on Indian Economy (DBIE), Reserve Bank of India website, whereas for OPI we resorted to International Financial Statistics (IFS) from International Monetary Fund. INF is expressed as percentage annual variation in the Wholesale Price Index[8] (WPI). GFD is expressed as a percentage of GDP and following Catao and Terrones (2005) and Lin and Chu (2013), Gross Fiscal deficit as a percentage of Narrow money (GFDD) is also scaled by NM for robustness purposes. GDPFC is the annual change in GDP at constant prices. NM is represented by the narrow money measure. TO is proxied by the sum of exports and imports both expressed as a percentage of GDP[9]. Average of three Oil price measures [10] in the foreign currency is first converted into rupee terms by multiplying the nominal $(\mathrm{EXR}=₹ / \$)$ of India with the respective oil price figures. Finally, OPI is calculated as the percentage annual variation in oil prices expressed in domestic currency. The inclusion of OPI in the analysis will portray the effect of oil price dynamism and EXR movements simultaneously. The definition of various variables is given below in Table 1 and the descriptive statistics are reported in Table 2.

\subsection{Empirical methodology}

\subsubsection{Causality examination}

4.2.1.1 Time-domain causality. To examine the time domain causality between fiscal deficit and INF, the study uses the well-known Toda and Yamamoto (1995) test, henceforth (TY) test. In the usual procedure of conventional Granger causality test, the lagged coefficients obtained through underlying VAR model are set equal to zero according to Wald's principle. However, Lütkepohl and Krätzig (2004) cautions about nonstandard limiting distributions of Wald's test statistic because of the co-integration properties of VAR model. These nonstandard asymptotic properties follow from the singularity of asymptotic distributions. To do away with the singularity nuisance, the TY test, supplemented the original VAR model with the maximum order of integration of variables. Moreover, the test performs better in case the variables are integrated and possibly cointegrated and the data is used in levels rather than in first differences [11].

The TY test is performed using the specifications 1 and 2 . It is to be noted that the standard Granger causality is based on VAR(k) model, wherein $\mathrm{k}$ is the appropriate length of lags of various variables reported by different lag selection criteria. However, in TY procedure, VAR $\left(k+d_{\max }\right)$ model is estimated. Here $d_{\max }$ denote the maximum order of integration of the variables suspected in the process. If we set lag length $\mathrm{k}$ equal to $p$ and $\mathrm{d}$ is reported as the highest order of integration, we proceed as:

$$
\begin{aligned}
& M_{t}=\theta_{0}+\theta_{i} \sum_{i=1}^{p} M_{t-i}+\theta_{d} M_{t-d}+\vartheta_{j} \sum_{j=1}^{p} N_{t-j}+\vartheta_{d} N_{t-d}+\varepsilon_{t} \\
& N_{t}=\theta_{0}^{\prime}+\theta_{i}^{\prime} \sum_{i=1}^{p} M_{t-i}+\theta_{d}^{\prime} M_{t-d}+\vartheta_{j}^{\prime} \sum_{j=1}^{p} N_{t-j}+\vartheta_{d}^{\prime} N_{t-d}+\epsilon \mathrm{t}
\end{aligned}
$$

$\mathrm{M}$ and $\mathrm{N}$ constitute the set of variables to be examined for analysis. Here zero restrictions are put to first $p$ parameters to test the null of no causality against an alternative one where the causality is supposed to exist. The test statistic is usually referred as modified Wald and follows a $\chi^{2}$ distribution with a degree of freedom equal to $p$ and supposed to be independent of the unit roots and cointegration. 


\begin{tabular}{|c|c|c|c|c|}
\hline Variables & Symbol & Description & Units & Source \\
\hline Inflation & INF & $\begin{array}{l}\text { Percentage annual variation in } \\
\text { the WPI }\end{array}$ & Percentage terms & DBIE-RBI \\
\hline $\begin{array}{l}\text { Gross fiscal } \\
\text { deficit }\end{array}$ & GFD & $\begin{array}{l}\text { Difference between the total } \\
\text { expenditure and total revenue } \\
\text { (excluding the market } \\
\text { borrowings) }\end{array}$ & Percentage of GDP & DBIE-RBI \\
\hline Gross fiscal deficit & GFDD & $\begin{array}{l}\text { Difference between the total } \\
\text { expenditure and total revenue } \\
\text { (excluding the market } \\
\text { borrowings) }\end{array}$ & Percentage of NM & DBIE-RBI \\
\hline $\begin{array}{l}\text { Gross domestic } \\
\text { product }\end{array}$ & GDPFC & $\begin{array}{l}\text { Annual change in gross } \\
\text { domestic product at constant } \\
\text { prices }\end{array}$ & Percentage terms & DBIE-RBI \\
\hline Call money rate & CMR & Weighted average CMRs & $\%$ per annum & DBIE-RBI \\
\hline Trade openness & TO & $\begin{array}{l}\text { Sum of exports and imports } \\
\text { both expressed as a } \\
\text { percentage of real gross } \\
\text { domestic product }\end{array}$ & Percentage of GDP & DBIE-RBI \\
\hline Oil price inflation & OPI & $\begin{array}{l}\text { Simple average of three spot } \\
\text { prices; UK Brent, West Texas } \\
\text { Intermediate and the Dubai } \\
\text { Fateh. }\end{array}$ & $\begin{array}{l}\text { Percentage annual } \\
\text { variation in oil prices } \\
\text { expressed in local } \\
\text { currency }\end{array}$ & IFS-IMF \\
\hline
\end{tabular}

Notes: DBIE-RBI = Database on Indian Economy-Reserve Bank of India; IFS-IMF = International Financial Statistics, International Monetary Fund

Source: Own elaboration

\section{Identifying fiscal inflation in India}

371

\begin{tabular}{|c|c|c|c|c|c|c|c|}
\hline Statistics & INF & GFD & GFDD & GDPFC & CMR & TO & OPI \\
\hline Mean & 7.209 & -5.080 & -29.771 & 5.631 & 8.668 & 9.776 & 2.322 \\
\hline Median & 6.471 & -5.080 & 29.699 & 6.053 & 8.220 & 8.900 & 5.914 \\
\hline Std.dev & 5.162 & 1.421 & 9.834 & 2.945 & 3.244 & 5.940 & 7.333 \\
\hline Skewness & 1.333 & -0.149 & -0.409 & -1.231 & 1.389 & 0.751 & -1.716 \\
\hline Kurtosis & 5.620 & 2.304 & 2.475 & 5.386 & 5.481 & 2.363 & 6.886 \\
\hline JB-stat & 27.369 & 1.125 & 1.852 & 23.021 & 27.183 & 5.223 & 52.650 \\
\hline$p$-value of JB-stat. & 0.000 & 0.569 & 0.396 & 0.000 & 0.000 & 0.073 & 0.000 \\
\hline Observations & 47 & 47 & 47 & 47 & 47 & 47 & 47 \\
\hline
\end{tabular}

Variable description

Source: Own elaboration

Table 2.

Descriptive statistics

4.2.1.2 Frequency domain causality. With a view to examine the issue of causality in the short and long-run, we use FD analysis. Statistically, FD refers to a domain for the examination of mathematical functions or signals at various frequencies instead of time, wherein a given stationary process is decomposed into a weighted sum of sinusoidal components with a certain frequency $(\Omega)$. Though the nature of the definition of causality remains same for both time and FDs, the framework of examination is different. Change of a signal over time is represented by a time-domain graph, whereas the magnitude of a signal within each frequency band over a range of frequencies is connoted by FD graph. More simply, time denotes the happening of a variation and frequency measures the strength of that variation. Though there are many approaches [12] available in the literature to conduct the Granger causality in FD analysis, we however, used the recently developed framework of Breitung and Candelon (2006), hereafter (BC). This approach 
JEFAS

25,50

372

has the advantage of being applicable to either a stationary set of variables or integrated but not cointegrated (data used in first differences) or both integrated and cointegrated (data is used in levels). In addition, FD analysis eliminates seasonal variations in case the data series used for analysis is short and the methodology accounts for non-linearities and causality cycles i.e. causality analysis at low and high frequencies.

Breitung and Candelon (2006) test between the two variables $\mathrm{M}$ and $\mathrm{N}$ can be performed through a VAR derived framework as [13]:

Let $V_{t}=\left(M_{t}, N_{t}\right)$ be a two-dimensional vector of time series obtained at $t=1 \ldots$.., $T$ with a finite-order VAR representation given by:

$$
\Theta(L) V_{t}=\mu_{t}
$$

where $\Theta(L)=1-\Theta_{1} L-\ldots-\Theta{ }_{p} L^{p}$ is a $2 * 2$ lag polynomial with is $L^{k} V_{t}=V_{t-k} . \mu_{t}$ is assumed to be a white noise process with the usual properties. Let $\mathrm{H}$ be the lower triangular matrix of the Cholesky decomposition $\mathrm{H}^{\prime} \mathrm{H}=\sigma^{-1}$, such that $\mathrm{E}\left(\epsilon_{t} \epsilon_{t}^{\prime}\right)=I$ and $\epsilon_{\mathrm{t}}=H \mu_{t}$. In case of a stationary system, the MA representation is given as:

$$
\begin{aligned}
V_{t} & =\varnothing(L) \mu_{t}=\left[\begin{array}{ll}
\varnothing_{11}(L) & \varnothing_{12}(L) \\
\varnothing_{21}(L) & \varnothing_{22}(L)
\end{array}\right]\left[\begin{array}{l}
\mu_{1 t} \\
\mu_{2 t}
\end{array}\right] \\
& =\varphi(L) \mu_{t}=\left[\begin{array}{ll}
\varphi_{11}(L) & \varphi_{12}(L) \\
\varphi_{21}(L) & \varphi_{22}(L)
\end{array}\right]\left[\begin{array}{l}
\epsilon_{1 t} \\
\epsilon_{2 t}
\end{array}\right]
\end{aligned}
$$

Here also $\varnothing(L)=\Theta(L)^{-1}$ and $\varphi(L)=\varnothing(L) H^{-1}$. This representation can be applied to derive the spectral density of $M_{t}$ as:

$$
f_{M}(\Omega)=\frac{1}{2 \pi}\left\{\left|\varphi_{11}\left(e^{-i \Omega}\right)\right|^{2}+\left|\varphi_{12}\left(e^{-i \Omega}\right)\right|^{2}\right\}
$$

The causality measure advocated by Geweke (1982) is defined as:

$$
\begin{gathered}
G_{N \rightarrow M}(\Omega)=\log \left[\frac{2 \pi f_{M}(\Omega)}{\left|\varphi_{11}\left(e^{-i \Omega}\right)\right|^{2}}\right] \\
=\log \left|1+\frac{\left|\varphi_{12}\left(e^{-i \Omega}\right)\right|}{\left|\varphi_{11}\left(e^{-i \Omega}\right)\right|}\right|
\end{gathered}
$$

If $\left|\varphi_{12}\left(e^{-i \Omega}\right)\right|^{2}=0$, then there is absence of causality from $\mathrm{N}$ to $\mathrm{M}$ at frequency $\Omega$. In case we have the elements of $V_{t}$ as integrated and possibly cointegrated, then FD causality measure can be represented through an orthogonalized MA specification:

$$
\Delta V_{t}=\varphi^{\prime}(L) \mu_{t}=\varphi^{\prime}(L) \mu_{t}
$$

Here $\varphi^{\prime}(L)=\varphi^{\prime}(L) H^{-1}$. It may be noted that in a two-variable co-integrated system $\delta^{\prime} \varphi^{\prime}(1)=0, \delta$ is a cointegration vector and $\delta^{\prime} V_{t}$ is a stationary process (Engle and Granger, 1987). Here again the associated causality measure is given by: 


$$
G_{N \rightarrow M}(\Omega)=\log \left|1+\frac{\mid \varphi_{12}^{\prime}\left(e^{-i \Omega}\right)}{\mid \varphi_{11}^{\prime}\left(e^{-i \Omega}\right)}\right| \mid
$$

We test the null of $G_{N \rightarrow M}(\Omega)=0$ to check whether N causes M or not at any frequency $\Omega$.

Breitung and Candelon (2006) provided a modified FD causality test by using the following reformulated VAR specification.

$$
M_{t}=\omega_{1} M_{t-1}+\ldots+\omega_{p} M_{t-p}+\partial_{1} N_{t-1}+\ldots+\partial_{p} N_{t-p}+\Phi_{t}
$$

The null hypothesis used in Geweke (1982), $G_{N \rightarrow M}(\Omega)=0$, has been reformulated by BC into, $H_{0}: R(\Omega) \omega=0$. Where $\omega$ constitutes a vector of coefficients of $\mathrm{N}$ and

$$
R(\Omega)=\left[\begin{array}{lll}
\cos (\Omega) & \cos (2 \Omega) \ldots & \cos (p \Omega) \\
\sin (\Omega) & \sin (2 \Omega) \ldots & \sin (p \Omega)
\end{array}\right]
$$

The $F$-statistic related to equation (12) follows $F(2, T-2 p)$ for $\Omega \in(0, \pi)$. It is to be noted that the causality between the two variables at the low frequency denotes the long-run causality and the short-run causality is represented at high frequency. If the variables are cointegrated then causality at zero frequency connotes long-run causality and in case of stationary variables there exists no such thing such as long-run causality, instead the lowfrequency causality implies the explanatory variable is able to predict the low-frequency component of dependent variable one period ahead.

4.2.1.3 Asymmetric cointegration. Primarily the study examines the existence of a longrun cointegration relationship between fiscal deficit and INF in case of the Indian economy. There are a number of linear tests [14] available in the literature to check for the existence or otherwise of cointegration. The limitation of these linear tests is that they assume a symmetrical association among the variables and ignore the possibility of any asymmetry in the nature of the relationship. The scholars like Shin et al. (2014) cautioned about the misleading repercussions of assuming explicitly a linear association among variables, and therefore, suggested to take account of possible asymmetries. This development of literature evaluating the issues of non-stationarity and non-linearity highlight the inadequacy of linear models to allow a more precise statistical inference and to produce authentic forecasts in case of situations featured with positive transaction costs and where policy implications are observed in-sample (Shin et al., 2014).

Doing away with linearities and taking cognizance of possible asymmetries, we applied an asymmetric NARDL model by Shin et al. (2014) for empirical analysis of long-run and short-run asymmetries among variables of interest. It is a convenient approach as it provides a dynamic error correction specification combined with the asymmetric long-run cointegration regression by decomposing a given time series $N_{t}$ into its oppositely signed partial sums $\left(N_{t}^{+}\right.$and $\left.N_{t}^{-}\right)$to take account of possible asymmetries. Second, it provides Bounds based test statistic, used to check for the existence of stable long-run association among variables of interest. Third, the method provides graphs of cumulative dynamic multipliers used to trace out the adjustment patterns following the positive and negative shocks to explanatory variables. The model is simple and comprehensive enough to permit any asymmetry switching from short-run to long-run or vice versa[15]. Such is the flexibility of this framework that it accommodates different specifications for the various possibilities 
JEFAS 25,50

of short-run and long-run asymmetry. Additionally, the NARDL model allows to test for the hidden cointegration, so that omitting any relationships, not apparent in a linear framework, is avoided[16].

The basic version of the model involves the following specification:

$$
M_{t}=\rho^{+} N_{t}^{+}+\rho^{-} N_{t}^{-}+\varepsilon_{t}
$$

Here $N_{t}$ is a $\mathrm{k} \times 1$ vector of segregated explanatory variables and $\rho^{+}$and $\rho^{-}$are the associated long-run asymmetric coefficients. The set of explanatory variables is decomposed as:

$N_{t}=N_{0}+N_{t}^{+}+N_{t}^{-}$and the partial sum decompositions of positive and negative components $\left(N_{t}^{+}\right.$and $\left.N_{t}^{-}\right)$are derived as:

$$
N_{t}^{+}=\sum_{i=1}^{t} \Delta N_{i}^{+}=\sum_{i=1}^{t} \max \left\{\Delta N_{i}, 0\right\} \text { and } N_{t}^{-}=\sum_{i=1}^{t} \Delta N_{i}^{-}=\sum_{i=1}^{t} \min \left\{\Delta N_{i}, 0\right\}
$$

Here $\Delta N_{i}$ represent the difference between successive values of the variable $\mathrm{N}$. The short-run asymmetric error correction model is depicted by:

$$
\Delta M_{t}=\gamma M_{t-1}+\delta^{+} N_{t-1}^{+}+\delta^{-} N_{t-1}^{-}+\sum_{i=1}^{p-1} \pi_{i} \Delta M_{t-i}+\sum_{i=0}^{q}\left(\beta_{i}^{+} \Delta N_{t-i}^{+}+\beta_{i}^{-} \Delta N_{t-i}^{-}\right)+\mu_{t}
$$

where $\delta^{+}=-\gamma \rho^{+}$and $\delta^{-}=-\gamma \rho^{-}$are long-run parameters, $\beta_{i}^{+}$and $\beta_{i}^{-}$represent the short-run asymmetric coefficients and $\mu_{t} \sim i i d\left(0, \sigma_{\mu}^{2}\right)$. It is to be noted that the construction of NARDL model in its error correction specification provides a solution for weak exogeneity of any non-stationary independent variable [17] and if the lag structure is correctly chosen, the residual serial correlation is also corrected (Shin et al., 2014).

The existence of cointegration among the variables is tested in terms of a null of $\gamma=\delta$ ${ }^{+}=\delta^{-}=0$, using the non-standard bounds based F statistic (Pesaran et al., 2001). This approach is applicable irrespective of whether the variables are integrated or stationary or a combination of both. From equation (14), we can check for following further possibilities: (i) $\delta=\delta^{+}=\delta^{-}$representing long-run symmetry, (ii) $\sum_{i=0}^{q} \beta_{i}^{+}=\sum_{i=0}^{q} \beta_{i}^{-}$, representing short-run symmetry or (iii) a combination of both short and long run symmetry [18]. The Wald's test statistic is used to decide about the presence or absence of above-stated hypothesis.

The study finally uses the non-linear cumulative dynamic multipliers to portray the route between disequilibrium position of short period and new long-run equilibrium of the system. The multipliers permit us to find out the asymmetric adjustment patterns following positive and negative shocks to explanatory variables. The diagrams have the important theoretical connotation of providing a way to illustrate the traverse to a new stable equilibrium position following any short-run disturbance from the long-run relationship (Shin et al., 2014). The cumulative dynamic multipliers of $N_{t}^{+}$and $N_{t}^{-}$on $M_{t}$ can be evaluated as follows:

$$
l_{h}^{+}=\sum_{i=0}^{h} \frac{\partial M_{t+i}}{\partial N_{t}^{+}} \text {and } l_{h}^{-}=\sum_{i=0}^{h} \frac{\partial M_{t+i}}{\partial N_{t}^{-}}, h=0,1 \ldots
$$

$l_{h}^{+}$and $l_{h}^{-}$converge to their associated long-run coefficients $\rho^{+}=\frac{-\delta^{+}}{\gamma}$ and $\rho^{-}=\frac{-\delta^{-}}{\gamma}$ as $h \rightarrow \infty$. Here again the explanatory variable $N_{t}$ is decomposed into its oppositely signed 
components around a zero threshold value to portray the behavior of dependent variable to these components.

So far, as the variables involved in the empirical analysis are concerned, the following nonlinear error correction models based on the error correction specification equation (14) are estimated.

$$
\begin{aligned}
& \Delta I N F_{t}=c+\lambda I N F_{t-1}+\pi_{1}^{+} G F D_{t-1}^{+}+\pi_{1}^{-} G F D_{t-1}^{-}+\pi_{2}^{+} C M R_{t-1}^{+}+\pi_{2}^{-} C M R_{t-1}^{-} \\
& +\pi_{3}^{+} \mathrm{GDPFC}_{t-1}^{+}+\pi_{3}^{-} \mathrm{GDPFC}_{t-1}^{-}+\pi_{4}^{+} \mathrm{TO}_{t-1}^{+}+\pi_{4}^{-} \mathrm{TO}_{t-1}^{-}+\pi_{5}^{+} \mathrm{OPI}_{t-1}^{+} \\
& +\pi_{5}^{-} \mathrm{OPI} 2_{t-1}^{-}+\sum_{i=1}^{p-1} \mu_{i} \Delta I N F_{t-i}+\sum_{i=0}^{q} \Omega_{1, i}^{+} \Delta G F D_{t-i}^{+}+\sum_{i=0}^{q} \Omega_{1, i}^{-} \Delta G F D_{t-i}^{-} \\
& +\sum_{i=0}^{q} \Omega_{2, i}^{+} \Delta C M R_{t-i}^{+}+\sum_{i=0}^{q} \Omega_{2, i}^{-} \Delta C M R_{t-i}^{-}+\sum_{i=0}^{q} \Omega_{3, i}^{+} \Delta G D P F C_{t-i}^{+} \\
& +\sum_{i=0}^{q} \Omega_{3, i}^{-} \Delta G D P F C_{t-i}^{-}+\sum_{i=0}^{q} \Omega_{4, i}^{+} \Delta T O_{t-i}^{+}+\sum_{i=0}^{q} \Omega_{4, i}^{-} \Delta T O_{t-i}^{-}+\sum_{i=0}^{q} \Omega_{5, i}^{+} \Delta O P I_{t-i}^{+} \\
& +\sum_{i=0}^{q} \Omega_{5, i}^{-} \Delta O P I_{t-i}^{-}+\epsilon_{1, t} \\
& \Delta I N F_{t}=d+\rho I N F_{t-1}+\pi_{1}^{+} G F D D_{t-1}^{+}+\pi_{1}^{-} G F D D_{t-1}^{-}+\pi_{2}^{+} C M R_{t-1}^{+}+\pi_{2}^{-} C M R_{t-1}^{-} \\
& +\pi_{3}^{+} \mathrm{GDPFC}_{t-1}^{+}+\pi_{3}^{-} \mathrm{GDPFC}_{t-1}^{-}+\pi_{4}^{+} \mathrm{TO}_{t-1}^{+}+\pi_{4}^{-} \mathrm{TO}_{t-1}^{-}+\pi_{5}^{+} \mathrm{OPI}_{t-1}^{+} \\
& +\pi_{5}^{-} \text {OPI } 2_{t-1}^{-}+\sum_{i=1}^{p-1} \mu_{i} \Delta I N F_{t-i}+\sum_{i=0}^{q} \Omega_{1, i}^{+} \Delta G F D D_{t-i}^{+}+\sum_{i=0}^{q} \Omega_{1, i}^{-} \Delta G F D D_{t-i}^{-} \\
& +\sum_{i=0}^{q} \Omega_{2, i}^{+} \Delta C M R_{t-i}^{+}+\sum_{i=0}^{q} \Omega_{2, i}^{-} \Delta C M R_{t-i}^{-}+\sum_{i=0}^{q} \Omega_{3, i}^{+} \Delta G D P F C_{t-i}^{+} \\
& +\sum_{i=0}^{q} \Omega_{3, i}^{-} \Delta G D P F C_{t-i}^{-}+\sum_{i=0}^{q} \Omega_{4, i}^{+} \Delta T O_{t-i}^{+}+\sum_{i=0}^{q} \Omega_{4, i}^{-} \Delta T O_{t-i}^{-}+\sum_{i=0}^{q} \Omega_{5, i}^{+} \Delta O P I_{t-i}^{+} \\
& +\sum_{i=0}^{q} \Omega_{5, i}^{-} \Delta O P I_{t-i}^{-}+\epsilon_{2, t}
\end{aligned}
$$

Identifying fiscal inflation in India

As usual, $c$ and $d$ constitute constants, $\lambda$ and $\rho$ denote the AR coefficients, $\pi_{i}^{+}, \pi_{i}^{-}$and $\Omega_{i}^{+}$, $\Omega_{i}^{-}$were $i=1,2,3,4$, are the long-run and short-run asymmetric coefficients and finally, $\epsilon_{i, t} \sim \ddot{i i d}\left(0, \sigma_{\epsilon_{i, t}}^{2}\right)$, respectively. Equation (16) estimates the asymmetric response of INF when the fiscal deficit is expressed as a percentage of GDP and equation (17) measures the asymmetric response of INF when the fiscal deficit is expressed as a percentage of narrow money. Although, the framework permits for complete symmetry, short-run asymmetry only, long-run asymmetry only, both short and long-run asymmetry and the partial asymmetry specifications, we applied a full asymmetry model in both the short and long-run. The motivation for choosing such a specification is provided by the various theoretical contours arguing for the existence of asymmetric linkages. 
JEFAS 25,50
The inclusion of various variables is strictly in accordance with the existing theory and the empirical evidence. While the GFD or GFDD is included according to the theoretical arguments of FTPL (Leeper, 1991; Sims, 1994 and Woodford, 2001), the seminal work of Sargent and Wallace (1981), the neoclassical, Keynesian and Monetarists. The fiscal deficit is largely considered to be inflationary, although the channels of transmission may assume various routes such as the consumption expenditure channel, money supply channel, import channel and the interest rate channel[19]. As a proxy for monetary policy actions, interest rate variable CMR is included and INF is expected to respond negatively to interest rate[20] through the traditional aggregate demand channel. To take account of the possible influence of structural factors[21], we include real GDP growth rate to act as a surrogate for output fluctuations in the economy. The increased output growth is expected to lower the INF by increasing the domestic availability of goods and services whereas a decrease in it escalates the inflationary pressures to denote the dearth of goods and services. Because of the increasing integration of Indian economy with the rest of world, TO is also included in the INF determination equation so as to test the validity of Romer (1993) hypothesis on India. The hypothesis argues for a negative association between openness and INF because of the time inconsistency of monetary policy in case of more open economies. Lastly, increasing dependence on oil imports[22] makes it imperative to include the oil price dynamics[23] and EXR fluctuations into the domain of empirical analysis. The increased oil prices are expected to trigger the inflationary pressures and a fall is expected to lower them, of course depending upon the extent of pass-through. Thus, a combination of factors related to monetary policy, fiscal policy, supply shocks and external factors are included in empirical exercise[24] for a comprehensive analysis.

\section{Empirical results and discussion}

\subsection{Unit root analysis}

We start with the examination of integration properties of the variables by applying the well-known Augmented Dickey and Fuller (1979) (ADF) test and Phillips and Perron (1988) (PP) test. To supplement the result outcomes of these two tests, Kwiatkowski et al. (1992) (KPSS) test is also applied. Using the appropriate specifications for each variable in each of the tests mentioned, the results shown in Table 3 report a mixture of stationary and nonstationary variables. INF, CMR, GDPFC and OPI are found I(0) and GFD, GFDD and TO are found to be $\mathrm{I}(1)$ at level and $\mathrm{I}(0)$ at first differences.

\subsection{Cointegration and causality analysis}

Prior to the causality evaluation, we first check whether the variables of prime interest i.e. INF and GFD and INF and GFDD have any cointegration relationship or not. As we have a mixture of $\mathrm{I}(0)$ and $\mathrm{I}(1)$ variables, the autoregressive distributed lag model or Bounds F-test as given by Pesaran and Shin (1998) and Pesaran et al. (2001), would be an appropriate method to apply. As reported in panel A of Table 4, the null of no cointegration is rejected between INF and GFD expressed as a percentage of GDP. As related to GFD expressed as a percentage of NM, results are akin to those reported in the first case. With the confirmation of the long-run association between the two variables, causality analysis in a time domain framework is examined through TY test.

Literature has highlighted that the direction of causality is not only from fiscal deficit to INF through the various transmission channels but also a feedback causality is also possible. INF can both increase and decrease the fiscal deficit. According to Aghevli and Khan (1978) Hypothesis, an increase in INF reduces the real value of government income and thereby necessitates it to borrow more to meet the expenditure requirements. With the 


\begin{tabular}{|c|c|c|c|c|c|}
\hline Variables & Test & Levels & First difference & Level & First difference \\
\hline \multirow[t]{3}{*}{$I N F$} & $\mathrm{ADF}$ & $-4.580^{*}$ & - & $-5.586^{*}$ & - \\
\hline & PP & $-4.515^{*}$ & - & $-5.017 *$ & - \\
\hline & KPSS & $0.389(5)$ & - & $0.087(5 \%)$ & - \\
\hline \multirow[t]{3}{*}{ CMR } & $\mathrm{ADF}$ & $-3.381^{* *}$ & - & $-3.577^{* *}$ & - \\
\hline & $\mathrm{PP}$ & $-3.280^{* * *}$ & - & $-3.502^{* * *}$ & - \\
\hline & KPSS & 0.267 (5) & - & 0.161 (1) & - \\
\hline \multirow[t]{3}{*}{$G D P F C$} & $\mathrm{ADF}$ & $-5.956^{*}$ & - & $-8.164^{*}$ & - \\
\hline & PP & $-6.096^{*}$ & - & $-8.209^{*}$ & - \\
\hline & KPSS & 0.604 (1) & - & 0.064 (5) & - \\
\hline \multirow[t]{3}{*}{$G F D$} & $\mathrm{ADF}$ & -2.565 & $-6.718^{*}$ & -2.465 & $-6.895^{*}$ \\
\hline & PP & -2.435 & $-7.709 *$ & -2.428 & $-7.907^{*}$ \\
\hline & KPSS & $0.804^{* *}$ & 0.215 (5) & 0.173** & $0.071(5)$ \\
\hline \multirow{3}{*}{$G F D D$} & $\mathrm{ADF}$ & -1.874 & $-7.455^{*}$ & -2.152 & $-7.554^{*}$ \\
\hline & PP & -1.829 & $-7.536^{*}$ & -2.021 & $-7.677^{*}$ \\
\hline & KPSS & $0.934^{*}$ & $0.229(5)$ & $0.167 * *$ & $0.058(5)$ \\
\hline \multirow[t]{3}{*}{ TO } & $\mathrm{ADF}$ & -1.046 & $-5.443 *$ & -1.479 & $-5.414^{*}$ \\
\hline & PP & -1.123 & $-5.484 *$ & -1.924 & $-5.459 *$ \\
\hline & KPSS & $0.785^{*}$ & 0.104 (5) & $0.178^{* *}$ & 0.105 (5) \\
\hline \multirow[t]{3}{*}{$O P I$} & $\mathrm{ADF}$ & $-6.344^{*}$ & - & $-6.452^{*}$ & - \\
\hline & $\mathrm{PP}$ & $-6.327^{*}$ & - & $-6.450 *$ & - \\
\hline & KPSS & $0.153(5)$ & - & 0.085 (5) & - \\
\hline
\end{tabular}

Identifying fiscal inflation in India

Notes: *; ** and *** denotes the rejection of null hypothesis against an alternative at $1 \%, 5 \%$ and $10 \%$ level of significance. $\mathrm{C}$ and $\mathrm{C}+\mathrm{T}$ refer to two alternative specifications denoting constant only and constant and a linear trend, respectively. ADF is Augmented Dickey-Fuller test (Dickey and Fuller, 1979), PP represents the Philips-Perron test (Philips and Perron, 1988) and KPSS denotes the Kwiatkowski et al. (1992) stationarity test. Schwarz information criteria is applied to choose the appropriate lag length for ADF test and Newey - West automatic selection procedure is used to choose the bandwidths for PP and KPSS tests

Table 3.

Unit root tests

$\begin{array}{lcc}\text { Cointegration test } & \text { Lag structure }(\text { AIC, SBC) } & \\ \text { Variables } & 1,0 & \text { Bounds value } \\ \text { INF and GFD } & 1,0 & 10.675^{*} \\ \text { INF and GFDD } & & 10.473^{*} \\ \text { Time-domain causality } & X_{S}{ }^{2} & \\ \text { Variables } & 19.443 & p \text {-value } \\ \text { GFD causes INF } & 2.5017 & 0.035^{*} \\ \text { INF causes GFD } & 22.014 & 0.990 \\ \text { GFDD causes INF } & 6.1367 & 0.037^{*} \\ \text { INF causes GFDD } & & 0.909\end{array}$

Notes: *Indicates statistical significance at 1\% significance level and the corresponding lower and upper bound critical values are 6.84 and 7.84 for ARDL Bounds test, respectively. For the time domain causality, Toda and Yamamoto (1995) test is applied. For the appropriate lag selection, AIC and SBC criteria's are used
Table 4.

Cointegration and time domain causality

result deficit rises and is known as INF-induced fiscal deficit (Heller, 1980). Similarly, excessive inflationary pressures mandate a contractionary policy stance on part of monetary authorities to control it. Higher nominal interest rates (Fisher effect) increase the debt interest payments of the already accumulated debt of the government and thereby trigger 
JEFAS

25,50

\section{8}

Figure 3.

FD causality (Breitung-Candelon test) further the deficit level. Similarly, according to Olivera-Tanzi effect, higher INF pressures can also lead to decline in the volume of tax collection and a deterioration of real tax proceeds being collected by the government because of time elapsed between the taxable event occurs and the collection of the tax becomes effective (collection lags) (Olivera, 1967; Tanzi, 1977)[25]. Thus because of deteriorated revenue position, deficit increases. Besides the positive association, the INF and budget deficit also move in reverse direction under certain circumstances. INF tax would be a type of tax revenue that leads to a fall in deficit. Similarly, if the borrowing is not indexed to the INF, any hike in the later will lower the real value of former through borrowing shocks.

The lower panel of Table 4 clearly provides an indication that fiscal deficit granger causes INF in India but feedback causality is absent. The presence of unidirectional causality and long-run cointegration relationship highlights the inflationary influence of deficit in India. The establishment of the unidirectional causality from fiscal deficit to INF is in accordance with the results of Ramu and Gayithri (2017).

The four parts of Figures 3(a)-3(d) portray the causality analysis in a FD framework using BC test. Part "a" of the figure shows that fiscal deficit causes INF only at lower frequencies or higher time periods. At the higher frequencies (short-run), the deficit is not found to cause the INF in India. Part "b" again provides an illustration of the absence of

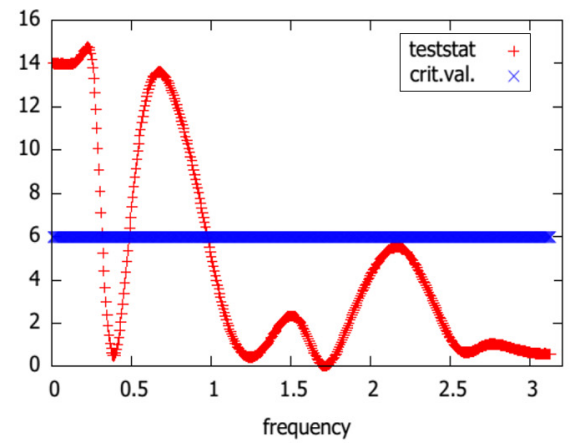

(a)

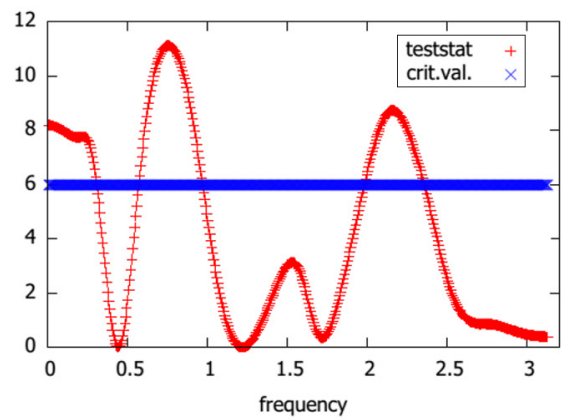

(c)

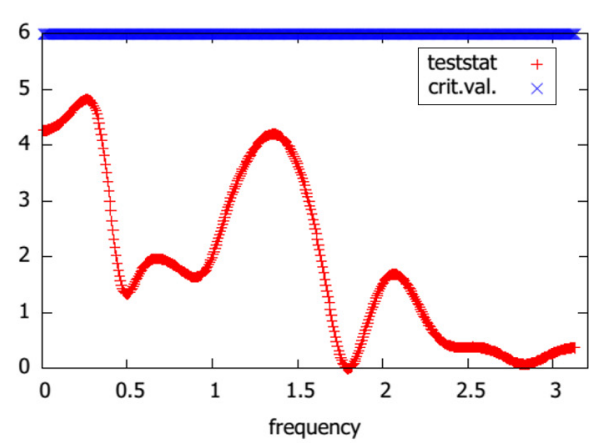

(b)

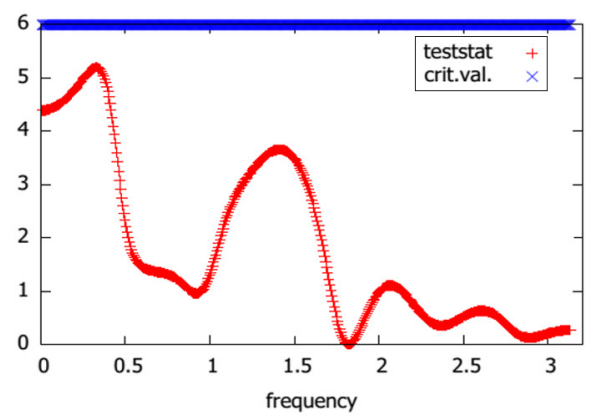

(d)
Notes: (a) BC test between GFD and INF; (b) BC test between INF and GFD; (c) BC test between GFDD and INF; (d) BC test between INF and GFDD 
feedback causality from INF to fiscal deficit in India at all frequencies. Thus, BC test documents that fiscal deficit need not be inflationary in the short-run, as the government can temporarily resort to other sources of financing the deficit instead of excess money creation in short-run (Sargent and Wallace, 1981; Catao and Terrones, 2005; Lin and Chu, 2013). The outcome of this result also validates the intrinsically dynamic nature of the relationship between these two variables. The parts "c" and "d" of the figure provides the results for robustness.

\subsection{Asymmetry analysis}

With a view to provide some insights about the possible asymmetry, if any, exists between the variables, the study applies NARDL model developed by Shin et al. (2014). We include INF, GFD, CMR, GDPFC, TO and OPI variables into the NARDL error correction specification (16). Since none of the variables is I(2), the application of NARDL is justified [26]. In addition, the adopted methodology would also take note of dynamic nature of the relationship, as the specification permits the lags of both dependent and independent variables to influence the dependent variable and also allows for intrinsic dynamic adjustment.

In this case, as well, the null of no cointegration is rejected like in the case of linear Bounds $F$-test, as both the $\mathrm{t}_{\mathrm{BDM}}$ and $\mathrm{F}_{\mathrm{pss}}$ tests, as reported at part $\mathrm{B}$ of Table 5 , are found to

\begin{tabular}{|c|c|c|c|c|c|c|}
\hline Asymmetry results & \multicolumn{3}{|c|}{ Long-run effect $(+)$} & \multicolumn{3}{|c|}{ Long-run effect (-) } \\
\hline Variables & Coef. & $F$-stat & $p$-value & Coef. & $F$-stat & $p$-value \\
\hline$G F D$ & 4.710 & 7.792 & $0.011^{*}$ & -0.071 & 4.236 & $0.049 * *$ \\
\hline CMR & -1.968 & 23.80 & $0.000^{*}$ & 0.522 & 4.466 & $0.046^{* *}$ \\
\hline$G D P F C$ & -1.605 & 20.41 & $0.000^{*}$ & 1.911 & 22.06 & $0.000 *$ \\
\hline TO & -0.389 & 2.012 & 0.170 & -0.723 & 3.542 & $0.073^{* * * *}$ \\
\hline$O P I$ & 0.065 & 2.063 & 0.165 & -0.048 & 0.805 & 0.379 \\
\hline & \multicolumn{3}{|c|}{$\begin{array}{c}\text { Long-run asymmetry } \\
W_{L R}\end{array}$} & \multicolumn{3}{|c|}{$\begin{array}{c}\text { Short-run asymmetry } \\
W_{S R}\end{array}$} \\
\hline & $F$-stat & $p$-value & & $F$-Stat & $p$-value & \\
\hline$G F D$ & 4.706 & $0.041 * *$ & & 3.114 & $0.091 * * *$ & \\
\hline$C M R$ & 18.64 & $0.000^{*}$ & & 8.085 & $0.009 *$ & \\
\hline$G D P F C$ & 4.516 & $0.045^{* * *}$ & & 4.584 & $0.044 * *$ & \\
\hline TO & 5.751 & $0.025^{* * *}$ & & 3.044 & $0.095^{* * *}$ & \\
\hline$O P I$ & 0.346 & 0.562 & & 2.754 & 0.111 & \\
\hline Cointegration test & $\begin{array}{l}F_{P S S} \\
4.450 * *\end{array}$ & $\begin{array}{c}t_{B D M} \\
-5.759^{* *}\end{array}$ & & & & \\
\hline Model diagnostics & Test statistics & $p$-value & & & & \\
\hline$\chi_{\mathrm{Sc}}^{2}$ & 16.88 & 0.660 & & & & \\
\hline$\chi_{\mathrm{BPG}}^{2}$ & 0.315 & 0.574 & & & & \\
\hline$\chi_{\mathrm{NOR}}^{2}$ & 2.381 & 0.304 & & & & \\
\hline Ramsey $F$ test & 1.309 & 0.330 & & & & \\
\hline
\end{tabular}

Notes: INF $=f(\mathrm{GFD}, \mathrm{CMR}, \mathrm{GDPFC}, \mathrm{TO}, \mathrm{OPI})$. Note: FPSS and tBDM are the long-run cointegration test statistics. *; ** and *** denote the $1 \%, 5 \%$ and $10 \%$ significance levels, respectively. $\chi_{S c}^{2}$ represent the portmanteau serial correlation test, $\chi_{B P G}^{2}$ denote the Breusch-Pagan-Godfrey heteroskedasticity test, Ramsey $F$ is the RESET test and finally the Jarque-Bera normality test is denoted by $\chi_{N O R}^{2}$. General to specific approach is followed, with an initial set up comprising $\max p=\max q=2$. The relevant $5 \%$ and $10 \%$ upper bound critical values of tBDM for $k=5$ (without taking partial decomposition into consideration) are -4.19 and -3.86 and for $k=10$ (when partial sum decompositions are independently treated as regressors) are -5.03 and -4.69 . Similarly, for the FPSS test the relevant $5 \%$ and $10 \%$ upper bound critical values for $k=5$ are 3.79 and 3.35 and for $k=10$ are 3.24 and 2.94, respectively
Identifying fiscal inflation in India 
JEFAS

25,50

380

be statistically significant at $5 \%$ significance level. The presence of a long-run cointegration relationship in an asymmetric framework provides an indication of the inflationary role of fiscal deficit in India. We followed a general to a specific approach for the estimation of asymmetric ARDL error correction model [27]. We started with $\max p=q=2$ as decided by $\mathrm{AIC}$ and SBC criteria's and zero restrictions are assigned to most of the insignificant lags to ensure precision and avoidance of noise into the dynamic multipliers. The part $\mathrm{C}$ of Table 5 reports the necessary diagnostic tests of the estimated model. Absence of serial correlation is accepted in case of the Portmanteau serial correlation test $\chi_{S c}^{2}$, heteroskedasticity in case of Breusch-Pagan-Godfrey test $\chi_{B P G}^{2}$, Ramsey RESET test (Ramsey F-test) validates the structural specification of model and finally, presence of normality is accepted in the Jarque-Bera test of normality $\chi_{N O R}^{2}$. Therefore, the stability conditions of estimated model are fulfilled.

With the detection of long-run association, we proceed to examine whether it is symmetrical or some asymmetry is involved. Wald's test with a null of symmetrical association between the variables is tested against an alternative of asymmetrical one. The $\left(\mathrm{W}_{\mathrm{LR}}\right)$ and $\left(\mathrm{W}_{\mathrm{SR}}\right)$ test statistics are shown in part $\mathrm{A}$ of Table 5 . The results document the presence of an asymmetrical long-run association between INF and GFD, INF and CMR, INF and GDPFC and INF and TO; however, the null of symmetrical association cannot be rejected between INF and OPI. The short-run asymmetry is also reported among the same pairs of variables and the null of symmetrical association cannot be rejected again in case of OPI as the $\mathrm{W}_{\mathrm{SR}}$ is found to be statistically insignificant.

The long-run coefficients of the inhabited relationship of various variables with the INF are shown in panel A of Table 5. In case of fiscal deficit, $G F D^{+}=4.710$ and $G F D^{-}=-0.071$. The establishment of a long-run direct association between the two variables provides an empirical support to the projections of Khundrakpam and Pattanaik (2010) and are in line with the findings of Rangarajan et al. (1989), Ramu and Gayithri (2017), Tran (2018). Surge in money supply (because of increased fiscal deficit and capital inflows) and the narrowing down of negative demand gaps in the economy provide a manifestation of inflationary role of fiscal deficit in India (Khundrakpam and Pattanaik, 2010). The positive impact of fiscal deficit on the INF of India can be attributed to the transmission channels such as the consumption expenditure channel, money supply channel, import channel and the interest rate channel and according to the theoretical arguments of Keynesians, Neo-Classicals and Monetarists. In fact, Ramu and Gayithri (2017) have exclusively tracked the first three of these transmission channels in case of India. Emerging countries, like India, featured with high fiscal deficit and public debt stocks are more exposed to inflationary pressures. Therefore, owing to their less fiscal space as may be needed for sustainability, these economies are vulnerable to higher default risks.

The signs of positive and negative coefficients are according to theory and both are statistically significant. However, increase in fiscal deficit is found to be more inflationary and the decreases in its affects the INF with a lower magnitude. In other words, the impact of fiscal position deterioration is more pronouncing and that of any fiscal improvement is milder or sluggish. Though it is not within the scope of present study to provide the underlying reasons of the asymmetric response of INF to positive and negative changes in fiscal deficit, however, the relevant theoretical underpinnings are worth mentioning. The possible asymmetry of fiscal deficit on INF in case of India can be explained through the existence of liquidity constraints, consumption-investment downward inflexibility and the downward price stickiness. Because of the existence of liquidity constraints as reflected through less developed credit markets and a large portion of population without adequate purchasing power in India, any increase in fiscal deficit would lead to an exacerbated increase in aggregate demand because of additional purchasing power with the 
individuals with limited liquidity hitherto and also enable individuals without constraints feel wealthier. Hence, impact on INF would be relatively higher. In case the deficit is reduced, people find it difficult to lower the consumption levels (Ratchet effect) drastically along with investment irreversibility, leading only to a marginal decline in demand conditions, and hence, a lower effect on INF is observed. The lower impact of reduced fiscal deficits on INF can also be explained through downward price stickiness. Producers are usually hesitant to price and wage reductions to avoid the worker-employ conflicts, secure the worker morale and secure some degree of price-setting power even in a supplyconstrained economy (Mohanty and John, 2015; Barnichon et al., 2017). Thus, the effect of contractionary fiscal action in-terms of a decline in deficit spending has a lower effect on INF.

Coming to the impact of monetary policy shocks as surrogated through CMR of interest, we found that the INF and interest rate are negatively related wherein a contractionary policy shock lowers it and an expansionary one raises it. The established negative association can operate through the conventional aggregate demand channel. However, contractionary policy stance is found to be more effective than the expansionary one, signifying the asymmetric influence of monetary policy actions on the INF of India. The reason for this asymmetry can be ascribed to the behavior of demand conditions because of changing outlook of firms and consumers, the binding liquidity constraints and the downward price stickiness under alternative monetary policy stances (Morgan, 1993; Barnichon et al., 2017). The changing outlook of firms and consumers could result in the asymmetric impacts, if the magnitude of pessimism is relatively high during economic downturns than they are optimistic during expansions or if the business and consumer confidence matters more during recessionary conditions [28]. As related to the credit constraints, tight monetary policy would be more effective than an easy one if the former makes banks less willing to lend to some riskier (subprime) borrowers. An increase in interest rate by the central bank leads to an upsurge in lending rates of commercial banks because of shifting of increased costs to the borrowers. The high lending rates could, in turn, increase the chances of borrower's default and as a result, banks become more risk-averse and very choosy in the credit supply, and hence, make them liquidity constrained. This leads to a lower level of investment, a reduction in household consumption i.e. a reduction in demand conditions, and hence, an appreciable fall in the price level (Barnichon et al., 2017). On the contrary, a cut in the interest rates through an easy policy action eliminate the credit constraints. However, if the demand for credit is lacking during an economic downturn, slacking the liquidity position may not necessarily augment the borrowings and higher spending. Therefore, impact of INF would be feeble. The substantial reduction of INF because of interest rate hike can also be explicated through the money supply channel. An increase in interest rate by the central bank leads to a rise in prime lending rate, a decline in credit supply, a fall in money supply via money multiplier process and finally to a lower level of the price level. On the other hand, a decrease in the interest rate during the retarded economic conditions will not necessarily lead to borrowing and spending augmentation of all economic agents in the economy, the effect of expansionary policy stance on INF will, therefore, be relatively lower[29] (Barnichon et al., 2017).

The impact of output growth and decline as represented by the positive and negativesum components of GDPFC is well according to the theory, but an asymmetry is reported. A negative growth in output is found to increase the INF relatively by a higher magnitude than the positive growth is found to reduce it. A decline in the output indicates the presence of supply constraints and given the demand conditions (if not increasing) the impact on price level will be higher. On the contrary, an increase in output growth cannot decrease the 
JEFAS 25,50

\section{2}

prices drastically because of the presence of the producer's price-setting power to some extent. Thus, in a supply-constrained economy, downward price rigidity leads to the asymmetric impact of output changes on INF.

As regard to the TO, although an asymmetry is reported, the signs refute the validation of Romer (1993) hypothesis in case of India. Specifically, the coefficient of $\mathrm{TO}^{+}$is -0.389 and that of $\mathrm{TO}^{-}$is -0.723 . The former is statistically insignificant and the latter is significant. The insignificance of $\mathrm{TO}^{+}$may be because of its ex-post measurement of openness only and lacks the ex-ante measurement. The negative component is significant, however and the sign establishes a direct association between these two variables. The direct link in case of India is in line with inflationary impact of outward - orientation for developing countries (Evans, 2007; Jalil et al., 2014; Ajaz et al., 2016).

Finally, as related to the impact of OPI, though signs are theoretically correct, yet both the positive and negative coefficients are weak and statistically insignificant. The possible explanation for such insignificance at the segregated asymmetry level is that the global oil prices have been converted to domestic oil prices by multiplying the former with the nominal EXR of the country concerned. The movements of the two variables, global oil prices and EXRs may not always be reinforcing but some counter-movements are also possible. There may be a fall in global oil prices, but because of the increased demand from the country at a lower global price, its EXR depreciates and the initial effect of declining oil prices will now get negated through increasing EXRs, and thus, the overall influence may be insignificant. In case of India, the depreciation of rupee more than offsets the favorable effect of the marginal decline in global commodity prices on domestic INF (RBI, 2013).

\subsection{Cumulative dynamic multipliers}

The graphical examination of dynamic effects of independent variables on the INF can be further portrayed through dynamic multipliers, as shown in Figure 4. The graphs plot the
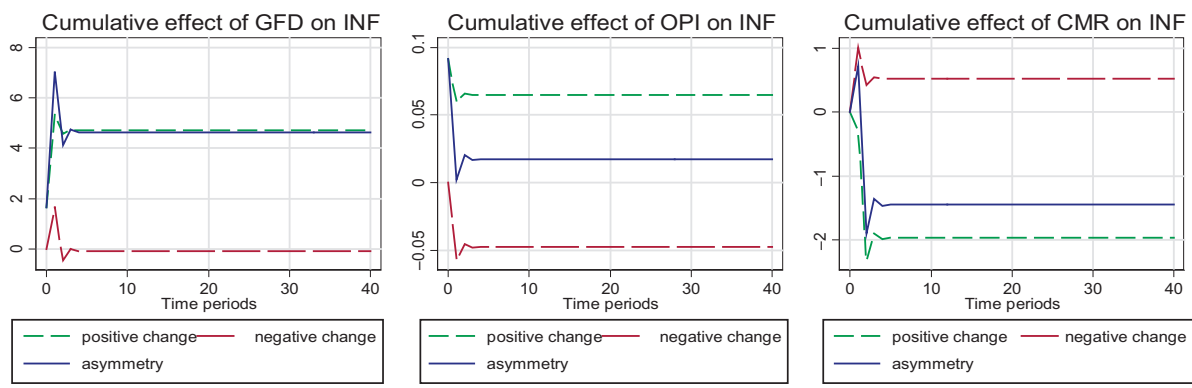

\section{Figure 4.}

Cumulative dynamic multipliers for Model 16
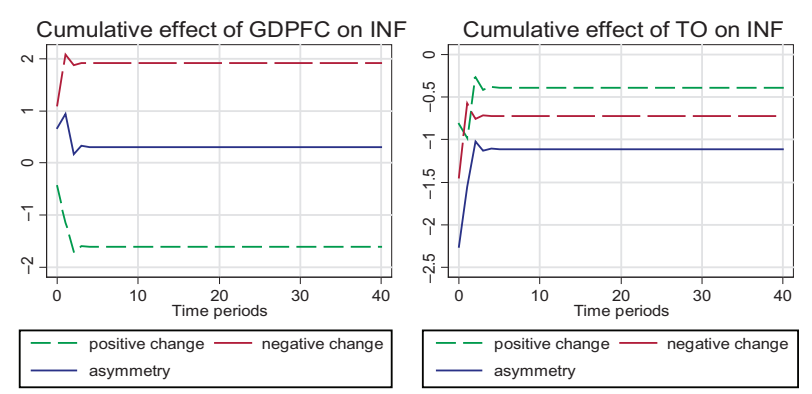
dynamic effects of positive and negative changes in the fiscal deficit, interest rate, output growth, TO and OPI on the INF of India. The blue line indicates the line of asymmetry and the value of this line at any given point measures the extent of asymmetry at that point. Figure 4 replicates all the results reported in Table 5, thus confirming the validity of above discussions. In case of fiscal deficit, asymmetry is stronger from the positive change and asymmetry persistence is observed even in the long-run. As related to the interest rate shocks, contractionary policy shock is more influential than the expansionary one and the asymmetry is observed in both the short and long-run. Similarly, expansion in output growth declines INF relatively by a lower magnitude than the increase in INF is caused by output decline. Finally, in case of OPI and TO, we found the same phenomenon as reported in Table 5. However, the coefficients associated with positive change in TO and with both positive and negative changes in case of OPI are statistically insignificant. Moreover, it takes around more than a year on average to reach to new equilibrium position following any short-run disturbance.

\subsection{Extensions}

The robustness of results is provided by using fiscal deficit as a percentage of narrow money in an economy as the key variable of analysis. Table 6 and Figure 5 reflect almost a mirror image of Table 5 and Figure 4, and therefore, prove the robustness of results[30].

Although, the study has attempted to explore the asymmetric nature of the relationship among selected variables, however, certain caveats to this investigation are warranted and an introspection into these caveats may provide a scope for further research in the area. To start with, a more structured analysis with robust theoretical underpinnings may enhance the understanding and findings of this study. Second, on the whole, unavailability of data
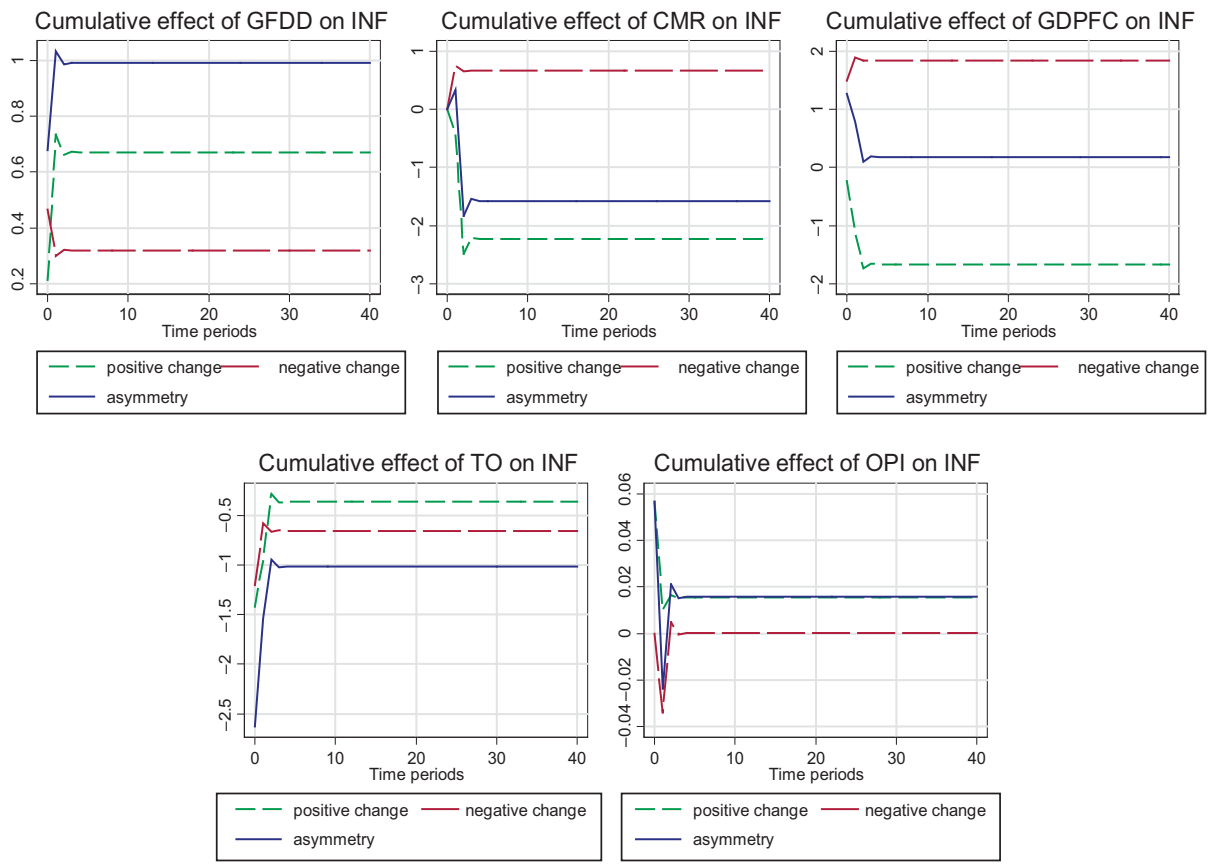

Figure 5. Cumulative dynamic multipliers for Model 


\begin{tabular}{|c|c|c|c|c|c|c|c|}
\hline \multirow{6}{*}{$\begin{array}{l}\text { JEFAS } \\
25,50\end{array}$} & Asymmetry results & \multicolumn{3}{|c|}{ Long-run effect (+) } & \multicolumn{3}{|c|}{ Long-run effect (-) } \\
\hline & Variables & Coef. & $F$-stat & $p$-value & Coef. & $F$-stat & $P$-value \\
\hline & $G F D D$ & 0.671 & 8.812 & $0.007^{*}$ & 0.320 & 2.019 & 0.169 \\
\hline & $C M R$ & -2.231 & 21.51 & $0.000 *$ & 0.657 & 6.137 & $0.021 * *$ \\
\hline & GDPFC & -1.663 & 19.13 & $0.000 *$ & 1.841 & 17.89 & $0.000 *$ \\
\hline & TO & -0.363 & 2.362 & 0.139 & -0.656 & 3.670 & $0.064^{* * * *}$ \\
\hline \multirow{14}{*}{384} & $O P I$ & 0.016 & 0.079 & 0.780 & 0.000 & 0.300 & 0.998 \\
\hline & & \multicolumn{3}{|c|}{$\begin{array}{l}\text { Long-run asymmetry } \\
W_{L R}\end{array}$} & \multicolumn{3}{|c|}{$\begin{array}{c}\text { Short-run asymmetry } \\
W_{S R}\end{array}$} \\
\hline & & $F$-stat & $p$-value & & $F$-Stat & $p$-value & \\
\hline & $G F D D$ & 6.153 & $0.021 *$ & & 3.269 & $0.084^{* *}$ & \\
\hline & $C M R$ & 17.81 & $0.000^{*}$ & & 9.697 & $0.005^{*}$ & \\
\hline & GDPFC & 1.132 & 0.299 & & 8.000 & $0.010^{* *}$ & \\
\hline & TO & 5.833 & $0.024 * *$ & & 6.908 & $0.015^{* *}$ & \\
\hline & $O P I$ & 0.236 & 0.632 & & 0.098 & 0.756 & \\
\hline & Cointegration test & $\begin{array}{l}F_{P S S} \\
4.721^{* *}\end{array}$ & $\begin{array}{c}t_{B D M} \\
-5.551^{* *}\end{array}$ & & & & \\
\hline & Model diagnostics & Test statistics & $p$-value & & & & \\
\hline & $\chi_{\mathrm{Sc}}^{2}$ & 15.31 & 0.758 & & & & \\
\hline & $\chi_{\mathrm{BPG}}^{2}$ & 0.364 & 0.546 & & & & \\
\hline & $\chi_{\mathrm{NOR}}^{2}$ & 0.296 & 0.862 & & & & \\
\hline & RAMSEY $F$ _test & 0.607 & 0.163 & & & & \\
\hline
\end{tabular}

Notes: $\mathrm{INF}=f(\mathrm{GFDD}, \mathrm{CMR}, \mathrm{GDPFC}, \mathrm{TO}, \mathrm{OPI})$. Note: $\mathrm{F}_{\mathrm{PSS}}$ and $\mathrm{t}_{\mathrm{BDM}}$ are the long-run cointegration test statistics. *; ** and *** denote the 1,5 and $10 \%$ significance levels, respectively. $\chi_{S c}^{2}$ represent the portmanteau serial correlation test, $\chi_{B P G}^{2}$ denote the Breusch-Pagan-Godfrey heteroskedasticity test, Ramsey $F$ is the RESET test and finally the Jarque-Bera normality test is denoted by $\chi_{N O R}^{2}$. General to

Table 6.

Long and short-run asymmetry results (Model 17) specific approach is followed, with an initial set up comprising $\max p=\max q=2$. The relevant $5 \%$ and $10 \%$ upper bound critical values of $\mathrm{t}_{\mathrm{BDM}}$ for $k=5$ (without taking partial decomposition into consideration) are -4.19 and -3.86 and for $k=10$ (when partial sum decompositions are independently treated as regressors) are -5.03 and -4.69 . Similarly, for the $\mathrm{F}_{\mathrm{PSS}}$ test the relevant $5 \%$ and $10 \%$ upper bound critical values for $k=5$ are 3.79 and 3.35 and for $k=10$ are 3.24 and 2.94 , respectively

for sufficiently longer periods of time acted both a challenge and hindrance for the exploration of a more comprehensive analysis. Although, the asymmetries have been observed in the empirical exercise with respect to the response of INF to various macroeconomic variables and the probable theoretical reasons were advocated, however, an identification of exact transmission channels of asymmetry would enrich the analysis.

\section{Conclusion}

Higher INF has always been considered as a growth retarding factor and a means of reducing the welfare standards of common masses. Therefore, maintaining a stable price level featuring a low INF rate has remained a high priority objective of macroeconomic management of various economies including India. Among the many factors fueling the inflationary tendencies in an economy such as monetary shocks, structural shocks, demand shocks, external shocks and demographic changes, the issue of INF has also been found to be related to fiscal policy decisions of the government. The primary purpose of the study is to evaluate the inflationary tendencies in India particularly from the fiscal point of view. We examined the causality between fiscal deficit and INF in a time domain and FD framework. We found a unidirectional causality running from fiscal deficit to INF in case of time-domain analysis and no feedback causality is reported. However, in case of FD design, causality from fiscal deficit to INF is found at low frequencies only, i.e. no short-run causality is 
established, and hence, dynamic nature of the relationship between the two variables is justified. Using NARDL model, we examined the nature of association in an asymmetric framework. The results document the existence of an asymmetric long-run direct association between fiscal deficits and INF. The outcome of this result is an indication of the inflationary role of fiscal deficit in India. However, the increase in the deficit is found to be more inflationary and the decrease in fiscal deficit is found to affect the INF with a lower magnitude. The possible asymmetry of fiscal deficit on INF can be explained through the existence of liquidity constraints, consumption-investment downward inflexibility and the downward price stickiness.

The other control variables used in the empirical exercise also reported the theoretically plausible results. Contractionary monetary policy action is found to be more effective than the expansionary one, signifying the asymmetric influence of monetary policy on the INF of India. Similarly, in a supply-constrained economy with downward price rigidity, we found an asymmetric impact of output growth and output decline on INF. As regard to the TO, although an asymmetry is reported, the signs refute the validation of Romer (1993) hypothesis in case of India. Finally, the impact of OPI on the inflationary pressures is according to theory but the coefficients are devoid of statistical significance.

The results documented above justified the application of NARDL into the empirical exercise. Thus, instead of assuming the linear nature of model specification (with the associated possibility of inappropriate policy conclusions), we proceeded with a well behaved and theoretically supported non-linear specification to take cognizance of dynamic nature of the relationship and that of observed asymmetries. These results indicate some important policy recommendations. Fiscal consolidation strategy should be executed in an appreciable manner to achieve the sound fiscal health and lower INF. The disciplined fiscal strategy would also be imperative for an effective monetary policy. Monetary authorities should possess noticeable credibility to manage the macroeconomic system and policy stances should be implemented according to requirements of the economy. Growth in output should be encouraged to have two-fold benefits to the economy - reducing INF on the one hand and fiscal deficits on the other [31].

\section{Notes}

1. "Governments running persistent deficits have sooner or later to finance those deficits with money creation (seigniorage), and thus producing inflation", Sargent and Wallace (1981).

2. The Government of India brought the Fiscal Responsibility and Budget Management Act, 2003 (FRBMA) since the Indian policymakers felt the need to improve the fiscal positions and ameliorate the macroeconomic management to move toward a nearly balanced budget regime featured with strengthened fiscal prudence. The Act aimed at elimination of revenue deficit completely and reduction of fiscal deficit to a manageable level of $3 \%$ of GDP by 2007 . However, because of the International financial crisis (2007-2008), the targets of the Act were initially postponed and later suspended in 2009.

3. Even recently, for the relevance of fiscal consolidation process, the N.K. Singh panel (2017) was setup to review the fiscal discipline strategy in India. The Committee advocated that a rule based fiscal policy by limiting government debt, fiscal deficit and revenue deficits to certain targets is good for fiscal consolidation in India. The panel recommended the fiscal deficit target of $2.5 \%$ of GDP by the financial year 2022-2023. Unlike the FRBM Act, the report recommended a glide path to the fiscal targets i.e. a steady progress toward them and also suggested that there be some flexibility in the deficit targets strictly according to the needs of economy and that too within an acceptable deviation from the main targets. 


\section{JEFAS 25,50}

4. In the case of Keynesians, an increased fiscal deficit necessitated by an increase in public expenditure or tax cut leads to an increase in aggregate demand and hence exerts an upward pressure on price level in an economy (in case economy is operating above full employment level) or enhances the level of both output and price level (in case economy is operating on upward sloping aggregate supply curve). However, in case of Elmendorf and Mankiw (1999), a rise in debt would result in increased price levels by creating a positive wealth effect on households.

5. Specifically according to FTPL, price level in the economy is determined by the nominal debt to present value of future surpluses.

6. "If the market has a negative perception on the sustainability of the public debt, it will instigate an increase in price level to the extent required to restore the government budget constraint. The higher price level reduces the real value of the private portfolios. The higher the nominal government liabilities, the greater the adjustments required in the price level. As a result, the presence of budget deficit caused long-term INF equation; with money growth playing no role may constitute a strong support for the FTPL” (Lozano-Espitia, 2008; Ramu and Gayithri, 2017).

7. Even though Tran (2018) investigated the asymmetric impacts of fiscal imbalance on the key macroeconomic variables, however, the explicit exploration of the nature of association between fiscal deficit and INF has not been evaluated by taking into account the important determinants of inflation. In addition, only a partial asymmetric model is used and asymmetry with respect to fiscal deficit is considered.

8. INF measure in India has been usually provided by WPI because of the absence of a nation-wide representative Consumer Price Index

9. Openness lacks a unanimously accepted definition. The multitude of its dimensions render the construction of one single index rather complex. While some "single indices" provide only a measurement of economic dimension of openness such as TO, the IMF's restrictions measurement, Chinn-Ito index, etc., the "synthetic indices" measure its economic, social, political and environmental dimensions such as A.T. Kearney/Foreign Policy Globalization, KOF, Maastricht Globalization Index, New globalization index, etc. Each of these indices suffers from different limitations and the availability of sufficient data proves altogether a severe obstacle (Goldberg and Pavcnik, 2007). With a view to take note of the impact of economic dimension of openness, we used the trade ratio (sum of exports and imports expressed as a percentage of GDP of the country) as its proxy. However, it is to be noted that openness rather is a wider term and includes trade policy (restrictions on trade), geographical and economic characteristics of the country (Ajaz et al., 2016).

10. World crude oil price is represented by the simple average of three spot prices; UK Brent, West Texas Intermediate and the Dubai Fateh $(C O P)$ to be a representative price for oil in India.

11. For a detailed description of the test refer to Toda and Yamamoto (1995).

12. These include partial directed coherence and other approaches like those of Geweke (1982) and more recently by Breitung and Candelon (2006).

13. For a detailed account of test refer to Breitung and Candelon (2006).

14. Engle and Granger (1987), Phillips and Ouliaris (1990) (single equation residual tests), Johansen (1988) and Johansen and Juselius (1990) (system cointegration approach), ARDL-Bounds test by Pesaran and Shin (1998) (a modified single equation approach with a positive edge over Johansen procedure).

15. A positive shock may have a larger impact in short-run and a negative shock is found to be more influential in long-run (or vice-versa). 
16. Granger and Yoon (2002) introduced the term hidden cointegration. It means the existence of cointegration between two variables provided their positive and negative components are cointegrated. Therefore, a standard (linear) cointegration is a special case of hidden cointegration and hidden cointegration is a special case of non-linear cointegration.

17. The model resorts to reduced form data generating process for the weakly endogenous variable.

18. In this case the NARDL model reduces to the standard symmetric ARDL model given by Pesaran and Shin (1998).

19. For a discussion of these channels refer to Ramu and Gayithri (2017).

20. The importance of interest in the monetary policy transmission has increased because the RBI from May 2011 has modified the operating procedure of monetary policy to move toward a single policy repo rate, with average call money rate (CMR) being explicitly recognized as an operating target (Mohanty and John, 2015).

21. Under Structuralists view, INF originates from structural maladjustments, bottlenecks and rigidities of the economy (Maitra, 2016).

22. India's oil self-sufficiency has decreased from $22 \%$ in $2013-2014$ to $18 \%$ in $2016-2017$.

https://energy.economictimes.indiatimes.com/news/oil-and-gas/-indias-petroleum-import-bill-rose-9per-cent-last-fiscal-import-dependency-of-crude-rises-to-82-percent/58380805.

23. Barsky and Kilian (2004), Hamilton and Herrera (2004), Catao and Terrones (2005), Lin and Chu (2013), Mohanty and John (2015) have also included impact of oil prices into account.

24. Because of the lack of time series data on the age structure wise population numbers, the influence of demographic factors has not been evaluated in the study.

25. The collection delays are less important in the no or low INF episodes. However, when there is high inflation, the real value of the payment received by the government is low compared with the value it would have if it had been made immediately right after the taxable event. Thus, collection lag has an important bearing in the valuation of tax revenue during the periods of high inflation.

26. Ouattara (2006) mentions the invalidity of the estimated coefficients in case the series under investigation is integrated of order two.

27. The results are of error correction model (16) are reported in Table A1 in the Appendix.

28. Because of the higher pessimism during the recessionary periods, lower interest rates may not boost consumer spending and investments whereas the higher interest rates during booms lowers them by increasing their costs, however the optimism during the boom should not overweigh the pessimism during recession (Morgan, 1993).

29. During a contractionary policy stance, business investment and consumer expenditure on durable goods and housing are substantially more sensitive than other expenditures, however, on the contrary the response of output and INF to the expansionary policy stance is either negligible or generally insignificantly different from zero (Tenreyro and Thwaites, 2015). An increase in interest rate during an expansion leads to a reduced expansion because of increased costs, but the lower interest rates may not necessarily lead to increasing investments in a downturn.

30. Relative to Table 5, we found the additional insignificance of negative component of fiscal deficits and absence of long-run asymmetry in case of output growth. Again the error correction results for the Model (17) are reported in Table A2 in the Appendix.

31. Increase in output growth leads to an augmentation in tax revenues, and therefore, deficits are reduced. 


\section{JEFAS 25,50}

\section{References}

Aghevli, B.B. and Khan, M.S. (1978), "Government deficits and the inflationary process in developing countries”, Staff Papers - International Monetary Fund, Vol. 25 No. 3, pp. 383-416.

Ahking, F.W. and Miller, S.M. (1985), "The relationship between government deficits, money growth and inflation", Journal of Macroeconomics, Vol. 7 No. 4, pp. 447-467.

Ajaz, T., Nain, M.Z. and Kamaiah, B. (2016), "Inflation and openness in India: an asymmetric approach", Macroeconomics and Finance in Emerging Market Economies, Vol. 9 No. 2, pp. 190-203.

Ashra, S., Chattopadhyay, S. and Chaudhuri, K. (2004), "Deficit, money and price: the Indian experience", Journal of Policy Modeling, Vol. 26 No. 3, pp. 289-299.

Ball, R.J. (2017), Inflation and the Theory of Money, Routledge.

Barnhart, S.W. and Darrat, A.F. (1988), "Budget deficits, money growth and causality: further OECD evidence", Journal of International Money and Finance, Vol. 7 No. 2, pp. 231-242.

Barnichon, R., Matthes, C. and Sablik, T. (2017), "Are the effects of monetary policy asymmetric?", Richmond Fed Economic Brief, pp. 1-4.

Barsky, R.B. and Kilian, L. (2004), "Oil and the macroeconomy since the 1970s", Journal of Economic Perspectives, Vol. 18 No. 4, pp. 115-134.

Bhat, J.A. and Sharma, N.K. (2018), "The twin-deficit hypothesis: revisiting Indian economy in a nonlinear framework", Journal of Financial Economic Policy, Vol. 10 No. 3, pp. 386-405.

Breitung, J. and Candelon, B. (2006), "Testing for short - and long-run causality: a frequency-domain approach", Journal of Econometrics, Vol. 132 No. 2, pp. 363-378.

Catao, L.A. and Terrones, M.E. (2005), "Fiscal deficits and inflation”, Journal of Monetary Economics, Vol. 52 No. 3, pp. 529-554.

Click, R.W. (1998), "Seigniorage in a cross-section of countries", Journal of Money, Credit and Banking, Vol. 30 No. 2, pp. 154-171.

Cochrane, J.H. (2001), "Long-term debt and optimal policy in the fiscal theory of the price level", Econometrica, Vol. 69 No. 1, pp. 69-116.

Cochrane, J.H. (2005), "Money as stock”, Journal of Monetary Economics, Vol. 52 No. 3, pp. 501-528.

Cottarelli, C., Griffiths, M.E. and Moghadam, R. (1998), "The nonmonetary determinants of inflation: a panel data study", IMF Working Papers, Vol. 98 No. 23, p. 1.

Darrat, A.F. (1985), "Inflation and federal budget deficits: some empirical results", Public Finance Quarterly, Vol. 13 No. 2, pp. 206-215.

De Haan, J. and Zelhorst, D. (1990), "The impact of government deficits on money growth in developing countries", Journal of International Money and Finance, Vol. 9 No. 4, pp. 455-469.

Dickey, D.A. and Fuller, W.A. (1979), "Distribution of the estimators for autoregressive time series with a unit root", Journal of the American Statistical Association, Vol. 74 No. 366a, pp. 427-431.

Domaç, I. and Yücel, E.M. (2005), "What triggers inflation in emerging market economies?”, Review of World Economics, Vol. 141 No. 1, pp. 141-164.

Dornbusch, R., Sturzenegger, F., Wolf, H., Fischer, S. and Barro, R.J. (1990), "Extreme inflation: dynamics and stabilization", Brookings Papers on Economic Activity, Vol. 1990 No. 2, pp. 1-84.

Dwyer, G.P. (1982), "Inflation and government deficits”, Economic Inquiry, Vol. 20 No. 3, pp. 315-329.

Elmendorf, D.W. and Mankiw, N.G. (1999), "Government debt”, Handbook of Macroeconomics, Vol. 1, pp. 1615-1669.

Engle, R.F. and Granger, C.W. (1987), "Co-integration and error correction: representation, estimation, and testing”, Econometrica, Vol. 55 No. 2, pp. 251-276. 
Evans, R.W. (2007), "Is openness inflationary? Imperfect competition and monetary market power", Globalization and Monetary Policy Institute, Federal Reserve Bank of Dallas, GMPI Working Paper 1.

Fischer, S. and Easterly, W. (1990), "The economics of the government budget constraint", The World Bank Research Observer, Vol. 5 No. 2, pp. 127-142.

Geweke, J. (1982), "Measurement of linear dependence and feedback between multiple time series", Journal of the American Statistical Association, Vol. 77 No. 378, pp. 304-313.

Giannaros, D.S. and Kolluri, B.R. (1985), "Deficit spending, money, and inflation: some international empirical evidence”, Journal of Macroeconomics, Vol. 7 No. 3, pp. 401-417.

Goldberg, P.K. and Pavcnik, N. (2007), "Distributional effects of globalization in developing countries", Journal of Economic Literature, Vol. 45 No. 1, pp. 39-82.

Granger, C.W. and and Yoon, G. (2002), "Hidden cointegration. University of California San Diego", Economics Working Paper Series, 2.

Hamburger, M.J. and Zwick, B. (1981), "Deficits, money and inflation”, Journal of Monetary Economics, Vol. 7 No. 1, pp. 141-150.

Hamilton, J.D. and Herrera, A.M. (2004), "Oil shocks and aggregate macroeconomic behavior: the role of monetary policy: a comment”, Journal of Money, Credit, and Banking, Vol. 36 No. 2, pp. 265-286.

Heller, P.S. (1980), "Impact of inflation on fiscal policy in developing countries", IMF Staff Papers, Vol. 27 No. 4.

Jalil, A., Tariq, R. and Bibi, N. (2014), "Fiscal deficit and inflation: new evidences from Pakistan using a bounds testing approach", Economic Modelling, Vol. 37, pp. 120-126.

Johansen, S. (1988), "Statistical analysis of cointegration vectors", Journal of Economic Dynamics and Control, Vol. 12 Nos 2/3, pp. 231-254.

Johansen, S. and Juselius, K. (1990), "Maximum likelihood estimation and inference on cointegrationwith applications to the demand for money", Oxford Bulletin of Economics and Statistics, Vol. 52 No. 2, pp. 169-210.

Karras, G. (1994), "Macroeconomic effects of budget deficits: further international evidence", Journal of International Money and Finance, Vol. 13 No. 2, pp. 190-210.

Khundrakpam, J.K. and Goyal, R. (2009), Is the Government Deficit in India Still Relevant for Stabilisation? (No. 50905), University Library of Munich.

Khundrakpam, J.K. and Pattanaik, S. (2010), "Fiscal stimulus and potential inflationary risks: an empirical assessment of fiscal deficit and inflation relationship in India”, Journal of Economic Integration, Vol. 25 No. 4, pp. 703-721.

King, R.G. and Plosser, C.I. (1985), "Money, deficits, and inflation", Carnegie-Rochester Conference Series on Public Policy, Vol. 22, pp. 147-195.

Komulainen, T. and Pirttilä, J. (2002), "Fiscal explanations for inflation: any evidence from transition economies?", Economics of Planning, Vol. 35 No. 3, pp. 293-316.

Kwiatkowski, D., Phillips, P.C., Schmidt, P. and Shin, Y. (1992), "Testing the null hypothesis of stationarity against the alternative of a unit root: how sure are we that economic time series have a unit root?", Journal of Econometrics, Vol. 54 Nos 1/3, pp. 159-178.

Kwon, G., McFarlane, L. and Robinson, W. (2009), "Public debt, money supply, and inflation: a crosscountry study", IMF Staff Papers, Vol. 56 No. 3, pp. 476-515.

Laasch, O., Conaway, R. and Végh, C.A. (2002), "Modern hyper-and high inflations", Journal of Economic Literature, Vol. 40 No. 3, pp. 837-880.

Leeper, E.M. (1991), "Equilibria under 'active'and 'passive'monetary and fiscal policies”, Journal of Monetary Economics, Vol. 27 No. 1, pp. 129-147.

Leeper, E.M. and Yun, T. (2006), "Monetary-fiscal policy interactions and the price level: background and beyond", International Tax and Public Finance, Vol. 13 No. 4, pp. 373-409. 
JEFAS 25,50

Lin, H.Y. and Chu, H.P. (2013), “Are fiscal deficits inflationary?”, Journal of International Money and Finance, Vol. 32, pp. 214-233.

Loungani, M.P. and Swagel, M.P. (2001), "Sources of inflation in developing countries", (No. 1-198). International Monetary Fund.

Lozano-Espitia, L.I. (2008), "Budget deficit, money growth and inflation: evidence from the Colombian case”, Borradores de Economía; No. 537.

Lütkepohl, H. and Krätzig, M. (Eds). (2004), Applied Time Series Econometrics, Cambridge university press.

McCallum, B.T. (2001), "Indeterminacy, bubbles, and the fiscal theory of price level determination", Journal of Monetary Economics, Vol. 47 No. 1, pp. 19-30.

Maitra, B. (2016), "Inflation dynamics in India: relative role of structural and monetary factors", Journal of Quantitative Economics, Vol. 14 No. 2, pp. 237-255.

Mazumdar, D., Sarkar, S. and Mehta, B.S. (2017), "Inequality in India-I”, Economic and Political Weekly, Vol. 52 No. 30, pp. $47-56$.

Metin, K. (1998), "The relationship between inflation and the budget deficit in Turkey", Journal of Business and Economic Statistics, Vol. 16 No. 4, pp. 412-422.

Minford, A.P. and Peel, D. (2002), Advanced Macroeconomics, Edward Elgar Publishing.

Mohanty, D. and John, J. (2015), "Determinants of inflation in India”, Journal of Asian Economics, Vol. 36, pp. 86-96.

Morgan, D.P. (1993), “Asymmetric effects of monetary policy”, Economic Review-Federal Reserve Bank of Kansas City, Vol. 78, pp. 21-21.

Nguyen, B. (2015), "Effects of fiscal deficit and money M2 supply on inflation: evidence from selected economies of Asia”, Journal of Economics, Finance and Administrative Science, Vol. 20 No. 38, pp. 49-53.

Olivera, J.H. (1967), “Money, prices and fiscal lags: a note on the dynamics of inflation”, PSL Quarterly Review, Vol. 20 No. 82.

Ouattara, B. (2006), "Aid, debt and fiscal policies in Senegal”, Journal of International Development, Vol. 18 No. 8, pp. 1105-1122.

Pesaran, H.H. and Shin, Y. (1998), "Generalized impulse response analysis in linear multivariate models”, Economics Letters, Vol. 58 No. 1, pp. 17-29.

Pesaran, M.H. and Shin, Y. (1998), "An autoregressive distributed-lag modelling approach to cointegration analysis", Econometric Society Monographs, Vol. 31, pp. 371-413.

Pesaran, M.H., Shin, Y. and Smith, R.J. (2001), "Bounds testing approaches to the analysis of level relationships", Journal of Applied Econometrics, Vol. 16 No. 3, pp. 289-326.

Protopapadakis, A.A. and Siegel, J.J. (1987), "Are money growth and inflation related to government deficits? Evidence from ten industrialized economies", Journal of International Money and Finance, Vol. 6 No. 1, pp. 31-48.

Phillips, P.C. and Perron, P. (1988), "Testing for a unit root in time series regression”, Biometrika, Vol. 75 No. 2, pp. 335-346.

Phillips, P.C. and Ouliaris, S. (1990), “Asymptotic properties of residual based tests for cointegration”, Econometrica: Journal of the Econometric Society, Vol. 58 No. 1, pp. 165-193.

Ramu, M.A. and Gayithri, K. (2017), "Fiscal deficit and inflation linkages in India: tracking the transmission channels", Journal of Social and Economic Development, Vol. 19 No. 1, pp. 1-24.

Rangarajan, C., Basu, A. and Jadhav, N. (1989), "Dynamics of interaction between government deficit and domestic debt in India", RBI Occasional Papers, Vol. 10 No. 3, pp. 163-220.

Rangarajan, C. and and Mohanty, M.S. (1998), "Fiscal deficit, external balance and monetary growth", Reserve Bank of India Occasional Papers, 18, p. 6. 
Romer, D. (1993), “Openness and inflation: theory and evidence”, The Quarterly Journal of Economics, Vol. 108 No. 4, pp. 869-903.

Sargent, T.J. and Wallace, N. (1981), "Some unpleasant monetarist arithmetic, federal reserve bank of minneapolis", Quarterly Review, Vol. 5 No. 3.

Sarma, Y.S.R. (1982), "Government deficit, money supply and inflation in India', reserve bank of India”, Occasional Papers, June.

Shin, Y., Yu, B. and Greenwood-Nimmo, M. (2014), "Modelling asymmetric cointegration and dynamic multipliers in a nonlinear ARDL framework", Festschrift in Honor of Peter Schmidt, Springer, New York, NY, pp. 281-314.

Sims, C.A. (1994), "A simple model for study of the determination of the price level and the interaction of monetary and fiscal policy", Economic Theory, Vol. 4 No. 3, pp. 381-399.

Tanzi, V. (1977), "Inflation, lags in collection, and the real value of tax revenue", Staff Papers International Monetary Fund, Vol. 24 No. 1, pp. 154-167.

Tenreyro, S. and Thwaites, G. (2015), "DP10786 pushing on a string: US monetary policy is less powerful in recessions".

Toda, H.Y. and Yamamoto, T. (1995), "Statistical inference in vector autoregressions with possibly integrated processes", Journal of Econometrics, Vol. 66 Nos 1/2, pp. 225-250.

Tran, N. (2018), "Asymmetric effects of fiscal balance on monetary variables: evidence from large emerging economies”, Empirical Economics, Vol. 57 No. 3, pp. 1-32.

Woodford, M. (1994), "Monetary policy and price level determinacy in a cash-in-advance economy", Economic Theory, Vol. 4 No. 3, pp. 345-380.

Woodford, M. (1995), "Price-level determinacy without control of a monetary aggregate", CarnegieRochester Conference Series on Public Policy, Vol. 43, North-Holland, pp. 1-46.

Woodford, M. (2001), "Fiscal requirements for price stability", (No. w8072). National Bureau of Economic Research.

\section{Further reading}

Jadhav, N. (1994), Monetary Economics for India, Egully. com.

Reserve Bank of India (2012), Fiscal and monetary coordination. Report on Currency and Finance 20092012, RBI, Mumbai.

Reserve Bank of India (2013), "Macroeconomic and monetary developments first quarter review 20132014", available at: http://rbidocs.rbi.org.in/rdocs/Publications/PDFs/M290713FC66587B599.pdf (accessed 30 July 2013). 
Appendix

25,50

\begin{tabular}{|c|c|c|c|c|}
\hline \multirow{3}{*}{392} & Variables & coefficient & $t$-statistic & $p$-value \\
\hline & \multicolumn{4}{|l|}{ Dependent variable: $\Delta \mathrm{INF}$} \\
\hline & $I N F_{t-1}$ & -0.864 & -5.760 & 0.000 \\
\hline \multirow{22}{*}{$\begin{array}{l}\text { Table A1. } \\
\text { Nonlinear ARDL } \\
\text { error correction } \\
\text { Model } 16\end{array}$} & $\begin{array}{l}G F D_{t-1}^{+} \\
G F D_{t}^{-}\end{array}$ & $\begin{array}{l}5.693 \\
0.086\end{array}$ & $\begin{array}{l}2.920 \\
0.070\end{array}$ & $\begin{array}{l}0.008 \\
0.942\end{array}$ \\
\hline & $C M R_{t-1}^{+1}$ & $\begin{array}{r}0.000 \\
-2.379\end{array}$ & $\begin{array}{r}0.090 \\
-5.090\end{array}$ & 0.000 \\
\hline & $C M R_{t-1}^{-1}$ & -0.631 & -1.130 & 0.250 \\
\hline & $G D P F C_{t-1}^{+}$ & -1.941 & -4.290 & 0.000 \\
\hline & $G D P F C^{-1}-1$ & 2.309 & 4.380 & 0.000 \\
\hline & $T O_{t-1}^{+}$ & -0.471 & -1.470 & 0.156 \\
\hline & $T O_{t-1}^{--1}$ & -0.874 & -1.930 & 0.066 \\
\hline & $O P I_{t+1}^{+1}$ & 0.078 & 1.340 & 0.195 \\
\hline & $O P I_{t-1}^{-1}$ & 0.057 & 0.850 & 0.403 \\
\hline & $\Delta G F D_{t}^{+}$ & 1.649 & 1.210 & 0.240 \\
\hline & $\Delta G F D_{t-1}^{-}$ & -1.776 & -1.090 & 0.287 \\
\hline & $\Delta C M R_{t-1}^{+^{+}}$ & -2.086 & -3.010 & 0.006 \\
\hline & $\Delta C M R_{t-1}^{--1}$ & -0.382 & -1.200 & 0.242 \\
\hline & $\triangle G D P F C_{t}^{+}$ & -0.434 & -1.210 & 0.240 \\
\hline & $\triangle G D P F C_{t-1}^{+}$ & -0.711 & -2.090 & 0.048 \\
\hline & $\Delta G D P F C_{t}^{--1}$ & 0.101 & 2.950 & 0.007 \\
\hline & $\Delta T O_{t}^{+}$ & -0.813 & -1.350 & 0.192 \\
\hline & $\Delta T O_{t-1}^{+}$ & -0.679 & -1.140 & 0.268 \\
\hline & $\Delta T O_{t}^{--}$ & 1.441 & 1.690 & 0.105 \\
\hline & $\Delta O P I_{t}^{+}$ & 0.091 & 1.660 & 0.111 \\
\hline & Constant & 2.650 & 0.910 & 0.370 \\
\hline & \multicolumn{4}{|c|}{$\begin{array}{l}\text { Note: General to specific approach is followed, with an initial set up comprising } \max p=\max q=2 \text { and } \\
\text { most of the insignificant lags are eliminated out to ensure the precision in cumulative dynamic multipliers }\end{array}$} \\
\hline
\end{tabular}




\begin{tabular}{|c|c|c|c|c|}
\hline Variables & coefficient & $t$-statistic & $p$-value & $\begin{array}{l}\text { Identifyıng } \\
\text { fiscal inflation }\end{array}$ \\
\hline \multicolumn{4}{|c|}{ Dependent variable: $\Delta \mathrm{INF}$} & \multirow{7}{*}{393} \\
\hline$I N F_{t-1}$ & -0.734 & -5.550 & 0.000 & \\
\hline$G F D D_{t-1}^{+}$ & 0.761 & 3.010 & 0.006 & \\
\hline$G F D D_{t-1}^{-1}$ & -0.363 & -1.380 & 0.181 & \\
\hline$C M R_{t-1}^{+t-1}$ & -2.530 & -4.800 & 0.000 & \\
\hline$C M R_{t-1}^{-1}$ & -0.745 & -0.540 & 0.760 & \\
\hline$G^{\prime} P P C_{t-1}^{+}$ & -1.887 & -4.360 & 0.000 & \\
\hline $\mathrm{GDPFC}^{-1-1}$ & 1.976 & 4.180 & 0.000 & \multirow{18}{*}{$\begin{array}{r}\text { Table A2. } \\
\text { Nonlinear ARDL } \\
\text { error correction } \\
\text { Model } 17\end{array}$} \\
\hline$T O_{t-1}^{+}$ & -0.412 & -1.560 & 0.133 & \\
\hline$T O_{t-1}^{--1}$ & 0.744 & 1.720 & 0.100 & \\
\hline$O P I_{t-1}^{++_{1}^{+}}$ & 0.017 & 0.280 & 0.785 & \\
\hline$O P I_{-1}^{-1}$ & -0.000 & 0.000 & 0.998 & \\
\hline$\Delta G F D D_{t}^{+}$ & 0.214 & 1.070 & 0.295 & \\
\hline$\Delta G F D D_{t}^{-}$ & -0.464 & -1.730 & 0.097 & \\
\hline$\Delta C M R_{t-1}^{+}$ & -2.117 & -3.110 & 0.005 & \\
\hline$\triangle G D P F C_{t}^{+}$ & -0.235 & -0.630 & 0.534 & \\
\hline$\triangle G D P F C_{+-1}^{+}$ & 0.756 & 0.200 & 0.740 & \\
\hline$\Delta G D P F C_{t}^{-1}$ & 0.496 & 3.960 & 0.001 & \\
\hline$\Delta T O_{t}^{+}$ & -1.423 & -1.160 & 0.042 & \\
\hline$\Delta T O_{t-1}^{+}$ & -0.731 & -1.163 & 0.116 & \\
\hline$\Delta T O_{t}^{--}$ & 1.205 & 1.940 & 0.065 & \\
\hline$\Delta O P I_{t}^{+}$ & 0.057 & 1.070 & 0.298 & \\
\hline$\Delta O P I_{t-1}^{-}$ & 0.034 & 0.670 & 0.512 & \\
\hline Constant & 3.759 & 1.290 & 0.209 & \\
\hline \multicolumn{4}{|c|}{$\begin{array}{l}\text { Note: General to specific approach is followed, with an initial set up comprising } \max p=\max q=2 \text { and } \\
\text { most of the insignificant lags are eliminated out to ensure the precision in cumulative dvnamic multipliers }\end{array}$} & \\
\hline
\end{tabular}

\section{About the authors}

Javed Ahmad Bhat is a Doctoral Candidate at the School of Economics, University of Hyderabad, Hyderabad, India. His research interests include empirical macroeconomics, Public policy and applied time series analysis. Javed Ahmad Bhat is the corresponding author and can be contacted at: apjavaid.jn@gmail.com

Naresh Kumar Sharma is Professor and Dean School of Economics, University of Hyderabad, Hyderabad, India. His research areas include Economic Theory, Gandhian Economic Thought, Development Science and Technology. He has taught courses such as Mathematical Economics, General Equilibrium, Social Choice Theory and Time Series Econometrics.

For instructions on how to order reprints of this article, please visit our website: 